\title{
A review of the global conservation status of bats
}

\author{
Simon P. Mickleburgh, Anthony M. Hutson and Paul A. Racey
}

\begin{abstract}
There are 1,001 species of bats, almost a quarter of which are globally threatened. The Chiroptera Specialist Group of IUCN's Species Survival Commission has produced two Action Plans examining conservation issues for all species and detailing recommendations for action to conserve the most threatened species and habitats. These Plans are aimed principally at key decision makers as well as organisations and individuals who are promoting bat conservation issues. The underlying threat to bats is pressure on resources from increasing human populations that leads to the loss or modification of foraging habitats and roosts. Bats frequently have a negative public image that influences the response to the problems of rabies and vampire bats in Latin America and conflicts between bats and commercial fruit growers in other areas of the world. In some areas bats are
\end{abstract}

persecuted because people are ignorant of the life history of bats and their role in ecosystems, while in other areas bats are overexploited for food. There is also a general lack of information about the distribution, status, biology and ecology of many species. This review examines some of the more general issues relating to bat conservation. It provides information on bat faunas of all countries worldwide, and on the most threatened species. It highlights the priority areas where action is needed immediately at a global, regional or national level. It highlights in particular the global importance of islands and caves for bats.

Keywords Action Plan, bats, caves, Chiroptera, conservation priorities, islands.

\section{Introduction}

Bats belong to the Order Chiroptera, with 1,001 species divided into two suborders - the Megachiroptera (often known as Old World fruit bats) with 167 species and the Microchiroptera with 834 species (Mickleburgh et al., 1992; Hutson et al., 2001). Bats are recorded from all areas of the world except the Arctic and Antarctic and a few isolated oceanic islands. More than $20 \%$ of all mammal species are bats. In many countries bats are major contributors to mammalian biodiversity, while in some, particularly small oceanic islands, they are the only indigenous mammals and may play a vital role as 'keystone' species in ecosystems (Cox et al., 1992).

In 1992 Mickleburgh et al. (1992) reviewed conservation issues relating to megachiropteran bats, and the conservation status of the Microchiroptera was reviewed by Hutson et al. (2001). The publication of these two Action Plans permitted the first overview of conservation

Simon P. Mickleburgh (Corresponding author) Fauna \& Flora International, Great Eastern House, Tenison Road, Cambridge, CB1 2TT, UK.

E-mail: simon.mickleburgh@fauna-flora.org

Anthony M. Hutson Winkfield, Station Road, Plumpton Green, East Sussex, BN7 3BU, UK. E-mail: hutsont@pavilion.co.uk

Paul A. Racey Department of Zoology, University of Aberdeen, Tillydrone Avenue, Aberdeen, AB24 2TZ, UK. E-mail: p.racey@abdn.ac.uk

Received 2 July 2001. Revision requested 21 September 2001. Accepted 28 September 2001 issues relating to bats worldwide. Both documents were aimed at key decision-makers at the governmental level as well as those promoting bat conservation at an international, regional and national level. As such, the documents contained many specific conservation recommendations. The purpose of this review is to synthesize the available information and highlight the key issues that need to be tackled immediately at global, regional and national levels.

\section{Diversity and conservation status}

The greatest bat diversity is in the neotropics, with at least 83 genera and 288 species recorded (Appendix). One hundred and two bat species have been recorded for the Caribbean region, of which 23 are endemic. The country with the greatest number of species is Indonesia with 175. West, Central and Southern Africa and elsewhere in South-east Asia are also rich areas for bat diversity. In many cases the numbers of species recorded are underestimates because systematic surveys are incomplete. Australia has 75 bat species, 20\% of which are endemic, neighbouring Papua New Guinea has 91 species, and Europe has 35 species.

The status of all bat species were assessed using the IUCN Red List Categories (IUCN, 1994) (Table 1). Twelve bat species are confirmed as Extinct. A further 238 species, almost a quarter of the total, are threatened (i.e. Critically Endangered, Endangered or Vulnerable). 
Table 1 Number of bat species in each IUCN Red List category (see IUCN (1994) for details of the categories). All species except those in the Lower Risk: Least Concern category, which are not on the 2000 IUCN Red List, are included in Hilton-Taylor (2000).

\begin{tabular}{lcc}
\hline Category & $\begin{array}{l}\text { Number } \\
\text { of Species }\end{array}$ & \% of total \\
\hline 1. Adequate data & & \\
Extinct species & 12 & 1.2 \\
$\quad$ Extinct & 0 & 0.0 \\
$\quad$ Extinct in the Wild & & \\
Threatened species & 29 & 2.9 \\
$\quad$ Critically Endangered & 36 & 3.6 \\
$\quad$ Endangered & 173 & 17.3 \\
$\quad$ Vulnerable & & \\
Lower risk species & 212 & 21.2 \\
$\quad$ Lower Risk: Near Threatened & 0 & 0.0 \\
Lower Risk: Conservation Dependent & 479 & 47.8 \\
$\quad$ Lower Risk: Least Concern & & \\
2. Inadequate data & 60 & 6.0 \\
$\quad$ Data Deficient & 1001 & \\
TOTAL &
\end{tabular}

In the lower risk categories, 212 species are categorised as Near Threatened and 479 as Least Concern (i.e. they are not on the 2000 IUCN Red List). Sixty species are categorised as Data Deficient. In most cases these assessments were made using the limited amount of information currently available. Few bat species have been studied in detail across the whole of their range. Many assessments were made by predicting status based upon knowledge of current threats to habitats or roosts, or to similar species in other areas. In all cases the precautionary principle was applied, and it is likely that assessments will change as more information on biology, ecology, distribution and taxonomy becomes available.

\section{Major threats}

Many of the threats to bats can be directly related to increasing human populations that bring extra demands for land, food and other resources that ultimately results in the degradation or destruction of habitat for bats and other organisms. This pressure is especially acute in tropical countries where a large proportion of the population may live in rural areas and have relatively low incomes.

\section{Habitat loss or modification}

One of the most important but universally threatened habitats for bats is forest or woodland, used for roosting and feeding. While much attention has focused on the loss of primary forest in tropical and subtropical areas, the situation in temperate areas is equally serious in many cases. Certain forest types are of particular concern, for example dry forests in Latin America and the Caribbean. Some harvesting techniques can be particularly damaging to the forest structure, and logging activities may open up previously inaccessible areas to hunters, settlers and miners.

Landscape elements are important for bats (Verboom, 1998). Tree lines, hedgerows, canals and other linear elements are used by bats during flight and may provide vital connections between roosts and feeding areas, and their loss or disruption because of intensified agricultural practices may be highly detrimental to some species. In areas where agriculture has been practised at a less intensive level, such as in Central Europe, the threat to these cultural landscapes is a great concern for the conservation of bats and other organisms.

Worldwide, agriculture has had a major impact on many bat habitats. The negative effects of 'slash and burn' agriculture on bat populations have recently been seen in Laos (T. Guillen, pers. comm.), where the nomadic peoples of the Nam Et Highlands burn primary forest to plant crops. Slash and burn destroys vegetation cover and may also kill individual bats that use tree crevices as roosts, affecting many of the threatened species of bats. Pesticide usage in agriculture in the developed world has recently moved towards chemicals with reduced mammalian toxicity, but highly toxic alternatives such as DDT are still used in developing countries (Fenton \& Rautenbach, 1998). DDT has been widely used in Africa as a way of controlling the Anopheles mosquito, which spreads malaria (McGinn, 2001). Safer pyrethroid alternatives are now being used, although the use of DDT has been reintroduced in areas where resistance to pyrethroids has developed (McGinn, 2001). Such pesticides have been implicated in the decline of bat populations in the USA and Australia (Clark, 1981) and McWilliam (1994) showed that spraying with DDT increased the mortality of some bat species in Zimbabwe. Clearly, the threat to bat populations from DDT needs to be weighed against the threat to humans from malaria.

Natural events can also cause problems, especially on small islands in the Indian and Pacific Oceans that are regularly affected by tropical storms. A typhoon that hit Samoa and American Samoa in 1990 had a severe impact on populations of Pteropus tonganus and P. samoensis (Dashback, 1990). Following the storm many bats foraged on fallen fruit or in fallen trees, but because bats were unable to take flight from the ground they were vulnerable to predation and were killed in large numbers by domestic dogs, cats and pigs. Evidence from the Mariana Islands, Samoa and Vanuatu suggested that a 
major cause of post-storm mortality was increased hunting by humans (Pierson \& Rainey, 1992). Defoliation made roosting animals more visible, and a reduced food supply forced bats to forage diurnally, increasing opportunities to hunt them.

\section{Roost site loss or disturbance}

Woodland management practices can also negatively affect bats. Removal of dead trees or decaying branches from living trees can reduce the availability of potential roosting sites. Bats may be loyal to an area containing several roosts rather than a specific tree, suggesting that even trees not heavily used by bats may be important to them (Lewis, 1995; Barclay \& Brigham, 1996; Pierson, 1998).

Underground sites such as caves and mines are crucial to the survival of many bat species worldwide. In temperate countries such sites may be used for breeding in summer and hibernation in winter, whereas in tropical countries, where bats do not hibernate, caves and mines may provide roosts for large colonies. In areas with few natural caves, such as Australia, mines provide important alternative roost sites. For example, the endemic and vulnerable ghost bat Macroderma gigas is heavily reliant on mines in Australia, with one site containing 1,500 animals out of a total population of 10,000 (Phillips, 1990).

Abandoned underground mines may be threatened by resumption of activities such as open cast mining, and the sealing of abandoned workings, usually for safety reasons, can have a dramatic impact on bats. In Wisconsin in the USA more than 600,000 bats of four species were saved when two mines were protected from closure (Tuttle \& Taylor, 1998). Quarrying, particularly for limestone, is a major threat to caves in Asia. Samanar Hill in southern India has many caves used by bats, and only the cancelling of new quarrying leases has saved the site (Murphy, 1987).

Some of the larger bat colonies produce sufficient guano for it to be an important economic resource, and uncontrolled guano collection can result in disturbance of colonies. A similar problem exists where bats share caves with cave swiftlets. The nests of cave swiftlets are highly prized as a component of bird's nest soup, with the most valuable nests worth US $\$ 2,000-4,000$ per $\mathrm{kg}$ (Sankaran, 2001). Uncontrolled nest collection can disturb bat colonies, and concerns have been raised over dramatic declines in populations of naked bats Chieromeles torquatus in caves in Sarawak (L. S. Hall pers. comm.). Caves are also attractive to speleologists and tourists. Spectacular cave systems are a magnet for tourists, and poorly managed tourism can modify cave ecosystems and adversely affect bat populations. In a number of countries such as the UK and Australia there are agreements between conservationists and speleologists to minimise impacts on cave ecosystems (Hutson et al., 1995; Watson et al., 1997).

\section{Health issues}

There are human health concerns associated with bats including histoplasmosis, rabies-like lyssaviruses and classical rabies. Histoplasmosis is a group of diseases that have been linked to inhalation of the spores of Histoplasma capsulatum in bat caves, although the risk to humans is relatively small (Hutson et al., 2001). In Australia rabies-like lyssavirus has been isolated from megachiropteran bats, although again the threat to humans is small, particularly if appropriate precautions are taken when handling bats (Hall \& Richards, 2000).

Rabies is the main health issue associated with bats, particularly amongst vampire bats in Latin America (Brass, 1994). Rabies is also known to be widespread amongst insectivorous bats in the USA and Canada and during 1980-2000, 28 people died of strains of rabies virus associated with bats, particularly Lasionycteris noctivagans and Pipistrellus subflavus (Jackson \& Fenton, 2001). This has led to the issuance of strict guidelines for preventing human rabies (Centers for Disease Control and Prevention, 1999), and could pose a threat to the public image of bats in these countries. Vampire bats, which feed on blood and are vectors of bovine paralytic rabies, are potentially a more serious threat, principally to livestock. On a global scale, over 1929-1990 c. 500 human deaths have been attributed to bats (i.e. an average of $<10$ per year) (Brass, 1994). However, it has been estimated that an average of 100,000 cattle a year die from rabies, representing a loss of about $\$ 30$ million per year (Acha \& Arambulo, 1985). Of the three vampire species (Desmodus rotunda, Diphylla ecaudata and Diaemus youngi) only Desmodus is common. Most attempts to control the threat from vampire bats have been ineffective, and damaging to non-target species. Caves in Mexico have been sealed because of the purported presence of vampires, threatening non-target species using these sites (Pint, 1994). Bats have been destroyed in their roosts using dynamite, shotguns, smoke and fire, and cyanide gas. Other methods have targeted bats whilst they feed, and have included the application of poisons such as strychnine and arsenic to open wounds on cattle and the administration of low doses of anti-coagulants to cattle that leave them unaffected but which are fatal to bats (Brass, 1994). Vaccination of cattle is the most effective and specific control mechanism for rabies but this is relatively expensive (Arellano-Sota, 1988). Concerns over the 'rabies issue' led to a Resolution at the 11th International Bat Research Conference in Brazil 
in 1998 which called for a more carefully managed approach to the issue of vampire bats and rabies (Hutson et al., 2001).

Bats may also be victims of disease. Flying foxes (Pteropus species) in the Pacific are thought to have suffered on several occasions from mass mortality resulting from pandemic disease (Rainey, 1998). Pteropus species are generally colonial, and there have been reports of the dramatic impacts of disease on Pacific islands such as Fiji, the Solomon Islands, New Caledonia and the Federated States of Micronesia (Rainey, 1998). The origin of these diseases is not known, although the high mortality suggests that the bats were not previously exposed to the pathogen, which might have been inadvertently introduced by humans (Flannery, 1989)

\section{Persecution}

Bats are viewed with suspicion, if not outright fear, in many cultures. A combination of ignorance and perceived risks of damage or disease can lead to deliberate persecution. This is particularly the case where humans share their homes with bats. In Africa, molossid bats such as Mops condylurus, Tadarida aegyptiaca and Chaerephon pumilus frequently roost in houses, and destructive methods of exclusion, such as fumigation, may be used to deal with them (Taylor, 2000). However, in The Netherlands successful education campaigns have ensured that roosts of Eptesicus serotinus have remained undisturbed in houses even when the bats have tested positive for rabies (P. H. C. Lina, pers. comm.).

In areas where fruit is grown on a commercial scale and where fruit orchards have replaced forests that would otherwise have been key feeding areas, such as Israel, Australia and South Africa, flying foxes have been the targets of eradication campaigns (Makin \& Mendelssohn, 1987; Hall \& Richards, 2000). Although flying foxes usually feed on fruit too ripe for commercial use, they may damage other fruits, leading to economic losses. Efforts to control flying foxes have varied from fumigation of caves in Israel, resulting in the deaths of many insectivorous bats (Makin \& Mendelssohn, 1987), to culling $75 \%$ of the bat population on the Maldives every 3 or 4 years to "maintain a stable population" (Dolbeer et al., 1988). In Australia, conservationists are lobbying for the recognition of Pteropus poliocephalus as a threatened species, but this has not stopped plans to cull these animals in Melbourne Botanic Garden because of concerns over possible damage to roosting trees (L. Lumsden, pers. comm.). As with vampire bats, many of the management methods used to deal with this problem have been indiscriminate and ineffective. Only through closer liaison between conservationists and the fruit-growing industry can this problem be effectively addressed.

\section{Lack of information}

Lack of information makes assessing the status of populations difficult, this in turn hampers the development ,of appropriate conservation measures. Of the 1,001 species of bats, few have been well studied. For many, information about their status, biology and ecology is limited, and for some there is no information beyond that available when the species was first described. In some regions, particularly in Europe and North America, biologists have collated information on the distribution and status of species, but there are large areas of the world where basic distributional data are lacking. In South-east Asia, for example, recent studies in Viet Nam, Laos and Myanmar have dramatically increased the known numbers of species in these countries (Bates et al., 1997, 2000; Francis et al., 1999). What is known of the distribution of a species is often based on information from specimens in museum collections and may not reflect the actual distribution. Bats may undergo seasonal movements, resulting in their concentration in certain areas at certain times of year, which may give a false impression of their status. Also, the status of colonial species is easier to assess than for those that are widely dispersed. Taxonomic uncertainties make conservation planning difficult. This has been highlighted in Australia, where the status of many taxa remains uncertain (Duncan et al., 1999). Novel techniques, including DNA analysis, are helping to resolve some of these problems. New species of bats are frequently being described, even in relatively well studied areas. Recently, Pipistrellus pipistrellus, one of the commonest species in Europe, was found to be two species, the nominate form and Pipistrellus pygmaeus (Jones \& Barrett, 1999).

\section{Overexploitation for food}

The importance of bats as a food for humans is not well understood. It is known that larger species such as Pteropus and Acerodon have long been used by humans as a source of protein especially on Indian and Pacific Ocean islands. In the western Pacific there has been a commercial trade in flying foxes, centred on the island of Guam. Between 1981 and 1989 c. 13,000 flying foxes were imported into Guam each year (Wiles, 1992), resulting in declines of populations in exporting countries (Rainey, 1998). In 1989 this trade was largely stopped when all Pteropus and Acerodon species were included in Appendix I and II of CITES. However, some illegal hunting and international trade probably still occurs 
in the northern Marianas (Wiles, 1994; Worthington \& Taisacan, 1996). Although the level of exploitation of microchiropteran bats is largely unknown, a study in Laos suggested that this may be a serious threat (Francis et al., 1999). In all survey areas bats were eaten by local villagers and there were reports of large numbers being taken for food. In northern Laos thousands of bats were cooked for sale. In general, it is likely that the consumption of bats is widespread and is not a major threat where it involves common species. However, for some threatened species, or where trade becomes commercialized, the situation may be more serious.

\section{Conservation priorities}

The two Action Plans (Mickleburgh et al., 1992; Hutson et al., 2001) give detailed lists of conservation recom- mendations for bats worldwide. Some of the more important general issues relating to bat conservation are discussed below.

\section{Critically Endangered species}

Of the 238 species considered to be threatened (Table 1) conservation attention should focus initially on the 29 species that are categorised as Critically Endangered (Table 2). Seven species (Pteralopex acrodonta, P. anceps, P. atrata, P. pulchra, Pteropus insularis, P. molossinus and $P$. phaeocephalus) are found on small islands in the western Pacific where threats from increasing human populations and natural events, such as typhoons, are particularly high (Hutson et al., 2001). Six species (Nyctimene rabori, Hipposideros nequam, Paracoelops megalotis, Rhinolophus convexus, Pipistrellus anthonyi and P. joffrei) are

Table 2 Critically Endangered Bats, with the criteria used for their categorisation (see IUCN (1994) for details), and their distribution.

\begin{tabular}{|c|c|c|}
\hline Family/Species & Criteria for CR categorisation & Distribution \\
\hline \multicolumn{3}{|l|}{ Megachiroptera } \\
\hline \multicolumn{3}{|l|}{ PTEROPODIDAE } \\
\hline Aproteles bulmerae & $\mathrm{B} 1+2 \mathrm{C}$ & Papua New Guinea \\
\hline Latidens salimalii & $\mathrm{B} 1+2 \mathrm{c}, \mathrm{D}$ & India \\
\hline Nyctimene rabori & $\mathrm{A} 2 \mathrm{c}$ & Philippines (Negros) \\
\hline Pteralopex acrodonta & $\mathrm{A} 1 \mathrm{c}, \mathrm{B} 1+2 \mathrm{c}$ & Fiji \\
\hline Pteralopex anceps & $\mathrm{A} 1 \mathrm{c}$ & Papua New Guinea, Solomons \\
\hline Pteralopex atrata & A1c & Solomons \\
\hline Pteralopex pulchra & A1c & Solomons \\
\hline Pteropus insularis & A1cd & Federated States of Micronesia \\
\hline Pteropus livingstonei & $\mathrm{A} 1 \mathrm{c}+2 \mathrm{~cd}, \mathrm{~B} 1+2 \mathrm{c}, \mathrm{C} 2 \mathrm{a}$ & Comoros \\
\hline Pteropus molossinus & $\mathrm{B} 1+2 \mathrm{ce}$ & Federated States of Micronesia \\
\hline Pteropus phaeocephalus & $\mathrm{B} 1+2 \mathrm{e}$ & Federated States of Micronesia \\
\hline Pteropus pselaphon & $\mathrm{B} 1+2 \mathrm{ce}$ & Japan \\
\hline Pteropus rodricensis & $\mathrm{B} 1+3 \mathrm{~d}$ & Mauritius (Rodrigues) \\
\hline Pteropus voeltzkowi & $\mathrm{C} 2 \mathrm{a}$ & Tanzania (Pemba) \\
\hline \multicolumn{3}{|l|}{ Microchiroptera } \\
\hline \multicolumn{3}{|l|}{ EMBALLONURIDAE } \\
\hline Coleura seychellensis & $\mathrm{B} 1+2 \mathrm{cde}, \mathrm{C} 2 \mathrm{~b}, \mathrm{D}$ & Seychelles \\
\hline Taphozous troughtoni & $\mathrm{A} 1 \mathrm{ac}, \mathrm{B} 1+2 \mathrm{abcde}, \mathrm{D}$ & Australia \\
\hline \multicolumn{3}{|l|}{ HIPPOSIDERIDAE } \\
\hline Hipposideros nequam & $\mathrm{B} 1+2 \mathrm{c}$ & Malaysia \\
\hline Paracoelops megalotis & $\mathrm{B} 1+2 \mathrm{C}$ & Viet Nam \\
\hline \multicolumn{3}{|l|}{ RHINOLOPHIDAE } \\
\hline Rhinolophus convexus & $\mathrm{D}$ & Malaysia \\
\hline \multicolumn{3}{|l|}{ VESPERTILIONIDAE } \\
\hline Myotis cobanensis & $\mathrm{B} 1+2 \mathrm{C}$ & Guatemala \\
\hline Myotis planiceps & $\mathrm{B} 1+2 \mathrm{c}$ & Mexico \\
\hline Pharotis imogene & $\mathrm{B} 1+2 \mathrm{c}, \mathrm{C} 2 \mathrm{~b}$ & Papua New Guinea \\
\hline Pipistrellus anthonyi & $\mathrm{B} 1+2 \mathrm{C}$ & Myanmar \\
\hline Pipistrellus joffrei & $\mathrm{B} 1+2 \mathrm{c}$ & Myanmar \\
\hline Scotophilus borbonicus & A1c & Madagascar, Réunion \\
\hline Murina tenebrosa & $\mathrm{B} 1+2 \mathrm{c}, \mathrm{D}$ & Japan \\
\hline \multicolumn{3}{|l|}{ MOLOSSIDAE } \\
\hline Chaerephon gallagheri & $\mathrm{B} 1+2 \mathrm{C}$ & Democratic Republic of Congo \\
\hline Mops niangarae & $\mathrm{B} 1+2 \mathrm{c}$ & Democratic Republic of Congo \\
\hline Otomops wroughtoni & $\mathrm{B} 1+2 \mathrm{C}$ & India \\
\hline
\end{tabular}


Table 3 Families of bats, with number of species, number of threatened species (i.e. Critically Endangered, Endangered or Vulnerable), $\%$ threatened and general distribution.

\begin{tabular}{|c|c|c|c|c|}
\hline Family & $\begin{array}{l}\text { No. of } \\
\text { species }\end{array}$ & $\begin{array}{l}\text { No. of } \\
\text { threatened } \\
\text { species }\end{array}$ & $\%$ threatened & Distribution \\
\hline \multicolumn{5}{|l|}{ Megachiroptera } \\
\hline Pteropodidae & 167 & 58 & 34 & Europe, Africa, Arabia, Asia, Australia, Oceania \\
\hline \multicolumn{5}{|l|}{ Microchiroptera } \\
\hline Rhinopomatidae & 4 & 1 & 25 & Africa, Arabia, Asia \\
\hline Craseonycteridae & 1 & 1 & 100 & Thailand \\
\hline Emballonuridae & 48 & 14 & 29 & Americas, Europe, Africa, Arabia, Asia, Australia, Oceania \\
\hline Nycteridae & 14 & 2 & 14 & Africa, Arabia, Asia \\
\hline Megadermatidae & 5 & 1 & 20 & Africa, Asia, Australia \\
\hline Hipposideridae & 75 & 18 & 24 & Africa, Arabia, Asia, Australia, Oceania \\
\hline Rhinolophidae & 66 & 11 & 17 & Europe, Africa, Arabia, Asia, Australia \\
\hline Noctilionidae & 2 & 0 & 0 & Americas \\
\hline Mormoopidae & 8 & 1 & 13 & Americas \\
\hline Phyllostomidae & 151 & 29 & 19 & Americas \\
\hline Natalidae & 5 & 1 & 20 & Americas \\
\hline Furipteridae & 2 & 1 & 50 & Americas \\
\hline Thyropteridae & 3 & 1 & 33 & Americas \\
\hline Myzopodidae & 1 & 1 & 100 & Madagascar \\
\hline Vespertilionidae & 357 & 78 & 22 & Americas, Europe, Africa, Arabia, Asia, Australia, New Zealand, Oceania \\
\hline Mystacinidae & 2 & 1 & 50 & New Zealand \\
\hline Molossidae & 90 & 19 & 21 & Americas, Europe, Africa, Arabia, Asia, Australia, Oceania \\
\hline
\end{tabular}

found in South-east Asia, and four (Pteropus livingstonei, $P$. rodricensis, $P$. voeltzkowi and Coleura seychellensis) are found only on small islands in the Indian Ocean. Only two species are found in mainland Africa (Chaerephon gallagheri and Mops niangarae) and two in Central America (Myotis cobanensis and M. planiceps). There are no Critically Endangered species in South America despite the diversity of bats in this area.

\section{Taxonomically distinct species}

There are 18 families of bats, and most are represented by large numbers of species with widespread distributions (Table 3). However, two families, the Craseonycteridae and the Myzopodidae, are represented by a single genus and species: Craseonycteris thonglongyai from Thailand is categorised as Endangered and Myzopoda aurita from Madagascar as Vulnerable. The family Mystacinidae has one genus with two species, both endemic to New Zealand. One, Mystacina robusta, is thought to be Extinct, while the other, M. tuberculata, is categorised as Vulnerable. Five other bat families are represented by a single genus: the Rhinopomatidae (4 species), Nycteridae (14), Noctilionidae (2), Natalidae (5) and Thyropteridae (3). All of these families provide important reservoirs of taxonomic diversity and as such should receive particular attention.

\section{Endemic species}

Table 4 lists countries that have $>10$ endemic bat species. Of particular concern are Australia, Madagascar and Japan, where the bat faunas are relatively small. The general threat to bat species is especially acute in the latter two countries (Hutson et al., 2001).

\section{Islands}

Bats are recorded from many island nations. Many species of the family Pteropodidae are recorded largely or entirely from islands and 13 of the 29 Critically Endangered bats are found only on islands (Table 2). The threats on islands are accentuated by often limited habitat, rapidly increasing human populations and

Table 4 Countries with 10 or more endemic bat species.

\begin{tabular}{lclc}
\hline Country & $\begin{array}{l}\text { Total no. } \\
\text { of bats }\end{array}$ & $\begin{array}{l}\text { Total no. } \\
\text { of endemics }\end{array}$ & $\begin{array}{l}\text { \% of endemics } \\
\text { in bat fauna }\end{array}$ \\
\hline Indonesia & 175 & 24 & 13.7 \\
Australia & 75 & 15 & 20.0 \\
Madagascar & 28 & 14 & 50.0 \\
Mexico & 137 & 13 & 9.5 \\
Japan & 39 & 12 & 30.7 \\
Malaysia & 112 & 11 & 9.8 \\
Papua New Guinea & 91 & 10 & 11.0 \\
\hline
\end{tabular}


natural events such as typhoons and cyclones. Bats often form a significant proportion of the native mammalian fauna and their role as pollinators and seed dispersers in some ecosystems has led to their designation as 'keystone species', the demise of which could lead to a cascade of extinctions (Cox et al., 1992).

\section{Caves}

The largest bat colonies are found in caves, with one site, Bracken Cave in Texas in the United States, containing c. 20 million animals (McCracken, 1986). Key cave sites worldwide need to be identified and if necessary management regimens instigated to protect populations of bats and other important cave fauna and flora. Active cave conservation projects are already underway in countries such as the UK and USA (Hensley, 1992; Hutson et al., 1995; National Caving Association, 1997) and these can provide models for other countries. Caves are also of interest to other groups such as archaeologists and speleologists and their involvement can help strengthen the case for protecting sites. Inventories and long-term monitoring are needed for some of the more important sites.

\section{Education}

The general negative human perception of bats stems from an ignorance of their biology, ecology and role in ecosystems. Where educational campaigns have been instigated, views of bats have often changed dramatically. One particularly effective example is in the Comoros, where the establishment of a locally-run survey and educational programme focusing on the Critically Endangered endemic Pteropus livingstonei has been particularly successful at raising the profile of bats and their role in forest ecosystems (Action Comores, 1993, 1994, 1997). Educational campaigns need to be targeted not just at the general public, but also at other interest groups whose activities may impact bats. These include the forestry and mining sectors, archaeologists, speleologists, farmers, fruit growers, the tourist industry, the house building and maintenance industry, and local and national governments.

\section{Legal protection}

The legal protection that bats receive at a national level is variable and ranges from full protection of roosts and feeding areas to no protection. In some countries bats are still listed as vermin. Only two international agreements have been formulated specifically for bats: the Agreement on the Conservation of Bats in Europe (under the Bonn Convention) and the Program for the Conservation of Migratory Bats of Mexico and the United States (Hutson et al., 2001). Efforts should concentrate on improving the legal status of bats, expanding the scope of current international agreements and establishing new ones.

\section{Discussion}

The two IUCN Action Plans have provided for the first time a conservation overview of this important group of mammals. The megachiropteran Plan successfully highlighted conservation issues relating to this group and 15 of the 20 highest priority recommendations have been implemented. These have included the establishment of captive breeding programmes for threatened populations of Pteropus voeltzkowi and P. livingstonei, surveys of poorly known countries such as the Maldives and Solomon Islands, permanent enforcement personnel on Guam to monitor illegal trade in bats, a review of the interaction between bats and commercial fruit growers and more research on the role of bats as 'keystone species'. The task for microchiropteran bats is much greater, both because of the larger number of species involved and their wide distributions.

This review has highlighted a number of issues that require immediate attention if the conservation problems facing bats are to be tackled at a global scale. Two issues in particular stand out as being areas where a global or regional approach could be most successful. Islands and caves generally receive less attention from the conservation community but are crucial to the survival of bats. A large proportion of the most threatened bats are found on islands (Table 2), and bats are often significant contributors to mammalian diversity in these areas. The threat to bats is often greatest on islands and as such they should be the primary focus of any major bat conservation initiative. There are good examples of successful conservation campaigns on islands, particularly in the Indian Ocean, and these could be used as templates for action in other areas.

Caves house the largest bat colonies on earth and caves and karst have been identified as key habitats globally (Watson et al., 1997). Most of those interested in caves have similar aims, the protection of sites, and there are good examples of collaboration between interest groups (National Caving Association, 1997). A global register of caves that are important for bats would be a first step towards developing management plans for the most valuable caves.

The two Action Plans are just the beginning of a process that will continue for many years. Plans are already in motion to update the megachiropteran Plan and to establish a website that could be regularly updated with new information. Above all, these Plans are meant to be 
a stimulus to individuals and organisations to develop further plans that may focus on particular countries, regions, species or issues. The first two priority projects should focus on island bats and on cave conservation worldwide.

\section{Acknowledgements}

The Action Plans could not have been produced without the financial assistance and administrative support of Fauna \& Flora International and The Bat Conservation Trust. Financial support was also provided by IUCN through the Peter Scott Action Plan Fund. The importance of the contributions of the 200 or so bat experts worldwide cannot be stressed highly enough and the authors are very grateful for this assistance.

\section{References}

Acha, P.N. \& Arambulo III, P.V. (1985) Rabies in the tropics history and current status. In Rabies in the Tropics (eds E. Kuwert, C. Merieux, H. Koprowski \& K. Bogel), p. 343 Springer-Verlag, Heidelberg.

Action Comores (1993) The Final Report of the 1993 Action Comores Expedition to the Comoro Islands. Compiled by W.J. Trewhella and P.F. Reason. Fauna \& Flora International 100\% Fund Report.

Action Comores (1994) The Final Report of the 1994 Action Comores Expedition to the Comoro Islands. Compiled by W.J. Trewhella and P.F. Reason. Fauna \& Flora International 100\% Fund Report.

Action Comores (1997) Action Comores Report 1995-97. Including the 1995 Expedition to the Comoro Islands. Compiled by K.M. Clark, S.R.T. Garrett and P.F. Reason. Fauna \& Flora International 100\% Fund Report.

Aggundey, I.R. \& Schlitter, D.A. (1985) Annotated checklist of mammals of Kenya. I. Chiroptera. Annals of the Carnegie Museum, 53(5), 119-158.

Albuja Viteri, L. (1999) Murciélagos del Ecuador, 2nd edn. SENACYT and FUNDACYT, Quito, Ecuador.

Ansell, W.F.H. (1978) The Mammals of Zambia. National Parks and Wildlife Service, Chilanga.

Arellano-Sota, C. (1988) Vampire bat-transmitted rabies in cattle. Rev. Infect. Dis., 10(Suppl. 4), S707.

Aulagnier, S. \& Thevenot, M. (1986) Catalogue des Mammiferes Sauvages du Maroc. Institut Scientifique Charia Ibn Batouta BP, Rabat.

Baagøe, H.J. (2001) Danish bats (Mammalia: Chiroptera): Atlas and analysis of distribution, occurrence, and abundance. Steenstrupia, 26(1), 1-117.

Baeten, B., van Cakenberghe, V. \& de Vree, F. (1984) An annotated inventory of a collection of bats from Rwanda. Revue de Zoologie et de Botanique Africaines, 98, 183-196.

Barbour, R. \& Davis, R.H. (1969) Bats of North America. University Press of Kentucky, Lexington.

Barclay, R.M.R. \& Brigham, R.M. (eds) (1996) Bats and Forests Symposium, October 19-21, 1995, Victoria, British Colombia, Canada. Working Paper 23/1996, Research Branch, BC Ministry of Forests, Victoria.
Barquez, R.M., Mares, M.A. \& Braun, J.K. (1999) The bats of Argentina. Special Publications Museum Texas Tech University, 42, 1-275.

Bates, P.J.J. \& Harrison, D. (1997) Bats of the Indian Subcontinent. Harrison Zoological Museum, Sevenoaks.

Bates, P.J.J., Harrison, D.L., Jenkins, P.D. \& Walston, J.L. (1997) Three rare species of Pipistrellus (Chiroptera: Vespertilionidae) new to Vietnam. Acta Zoologica Academiae Scientiarum Hungaricae, 43(4), 359-374.

Bates, P.J.J., Nwe, T., Pearch, M.J., Swe, K.M., Hla Bu, S.S. \& Tun, T. (2000) A review of bat research in Myanmar (Burma) and results of a recent survey. Acta Chiropterologica, 2(1), 53-82.

Bauer, K. (1992) Laephotis botswanae - a bat new for Tanzania. In Prague Studies in Mammalogy (eds I. Horacek \& V. Vohralik), pp. 13-15. Charles University Press, Prague.

Benda, P. \& Horacek, I. (1998) Bats (Mammalia: Chiroptera) of the Eastern Mediterranean. Part 1. Review of distribution and taxonomy of bats in Turkey. Acta Societatis Zoologicae Bohemoslovenicae, 62, 255-313.

Benzal, J. \& De Paz, O. (1991) Los Murcielagos de España y Portugal. ICONA, Spain

Bergmans, W. (1988) Taxonomy and biogeography of African fruit bats (Mammalia, Megachiroptera). 1. General introduction; material and methods; results: the genus Epomophorus Bennett, 1836. Beaufortia, 38(5), 75-146.

Bergmans, W. (1989) Taxonomy and biogeography of African fruit bats (Mammalia, Megachiroptera). 2. The genera Micropteropus Matschie, 1899, Epomops Gray, 1870, Hypsignathus H. Allen, 1861, Nanonycteris Matschie, 1899, and Plerotes Andersen, 1910. Beaufortia, 39(4), 89-153.

Bergmans, W. (1990) Taxonomy and biogeography of African fruit bats (Mammalia, Megachiroptera). 3. The genera Scotonycteris Matschie, 1894, Casinycteris Thomas, 1910, Pteropus Brisson, 1762, and Eidolon Rafinesque, 1815. Beaufortia, 40(7), 111-177.

Bergmans, W. (1994) Taxonomy and biogeography of African fruit bats (Mammalia, Megachiroptera). 4. The genus Rousettus Gray, 1821. Beaufortia, 44(4), 79-126.

Bergmans, W. (1997) Taxonomy and biogeography of African fruit bats (Mammalia, Megachiroptera). 5. The genera Lissonycteris Andersen, 1912, Myonycteris Matschie, 1899 and Megaloglossus Pagenstecher, 1885; general remarks and conclusions; Annex: key to all species. Beaufortia, 47(2), 11-90.

Bonaccorso, F. (1998) Bats of Papua New Guinea. Conservation International, Washington DC.

Borg, J.J., Violani, C. \& Zava, B. (1997) The bat fauna of the Maltese Islands. Myotis, 35, 49-65.

Boye, P., Pott-Dorfer, B., Dorfer, K. \& Demetropoulos, A. (1990) New records of bats (Chiroptera) from Cyprus and notes on their biology. Myotis, 28, 93-100.

Brass, D.A. (1994) Rabies in Bats, Natural History, and Public Health Implications. Livia Press, Connecticut.

Breuil, M. \& Masson, D. (1991) Quelques remarques sur la biogeographie des chauves-souris des Petits Antilles. Compte Rendu de la Société de Biogéographie. Paris, 67(1), 25-39.

Centers for Disease Control and Prevention (1999) Human Rabies Prevention - United States, 1999. Recommendations of the Advisory Committee on Immunization Practices (ACIP). Morbidity and Mortality Weekly Report, Vol. 48 No. RR-1. US Department of Health and Human Services, Atlanta. 
Cheke, A.S. \& Dahl, J.F. (1981) The status of bats on Western Indian Ocean islands, with special reference to Pteropus. Mammalia, 45, 205-238.

Churchill, S. (1998) Australian Bats. New Holland Publishers, Sydney.

Clark, D.R. (1981) Bats and Environmental Contaminants A Review. USFWS Special Scientific Report No. 235.

Corbet, G.B. (1978) The Mammals of the Palaearctic Region: A Taxonomic Review. British Museum (Natural History), London and Cornell University Press, Ithaca.

Corbet, G.B. \& Hill, J.E. (1992) The Mammals of the Indomalayan Region; A Systematic Review. Oxford University Press, Oxford.

Cox, P.A., Elmqvist, T., Pierson, E.D. \& Rainey, W.E. (1992) Flying foxes as pollinators and seed dispersers in Pacific Island ecosystems. In Pacific Island Flying Foxes: Proceedings of an International Conservation Conference (eds D.E. Wilson \& G.L. Graham), pp. 18-23. US Fish and Wildlife Service Biological Report 90(23). US Department of the Interior, Fish and Wildlife Service, Washington DC.

Csorba, G., Kruskop, S.V. \& Borissenko, A.V. (1999) Recent records of bats (Chiroptera) from Nepal, with remarks on their natural history. Mammalia, 63, 61-78.

Dashback, N. (1990) After the hurricane. Bats, 8(3), 14-15.

DeBlase, A.F. (1980) The bats of Iran: systematics, distribution, ecology. Fieldiana: Zoology, New Series, 4, 1-424.

Dobrosi, D. (1995) A Handbook for the Conservation of Bats in Hungary. Hungarian Bat Research Society.

Dolbeer, R.R., Fielder, L.R. \& Rasheed, H. (1988) Management of fruit bat and rat populations in the Maldive Islands, Indian Ocean. In Proceedings of the Thirteenth Vertebrate Pest Conference (eds A.C. Crabb \& R.E. Marsh), pp. 112-118. University of California, Davis.

Duncan, A., Baker, G.B. \& Montgomery, N. (eds) (1999) The Action Plan for Australian Bats. Environment Australia, Canberra.

Eisenberg, J.F. (1989) Mammals of the Neotropics. Volume 1. The Northern Neotropics. The University of Chicago Press, Chicago and London.

Fenton, M.B. \& Rautenbach, I.L. (1998) Impacts of ignorance and human and elephant populations on the conservation of bats in African woodlands. In Bat Biology and Conservation (eds T.H. Kunz \& P.A. Racey), pp. 261-270. Smithsonian Institution Press, Washington DC.

Flannery, T.F. (1989) Flying foxes in Melanesia: populations at risk. Bats, 7(4), 5-7.

Flannery, T. (1995a) Mammals of New Guinea. Revised and expanded edition. Reed Books, Chatswood.

Flannery, T. (1995b) Mammals of the South-west Pacific and Moluccan Islands. Australian Museum and Reed Books, Chatswood.

da Fonseca, G.A.B., Herrmann, G., Leite, Y.L.R., Mittermeier, R.A., Rylands, A.B. \& Patton, J.L. (1996) Lista Anotada dos Mamíferos do Brasil. Occasional Papers in Conservation Biology Number 4. Conservation International, Washington DC.

Francis, C.M., Guillen, A. \& Robinson, M.F. (1999) Order Chiroptera: Bats. In Wildlife in Lao PDR. 1999 Status Report (compilers J.W. Duckworth, R.E. Salter \& K. Khounboline), pp. 225-235. IUCN - The World Conservation Union, Wildlife Conservation Society and Centre for Protected Areas and Watershed Management, Lao PDR.

Gaisler, J. (1983-84) Bats of northern Algeria and their winter activity. Myotis, 21-22, 89-95.
Garbutt, N. (1999) Mammals of Madagascar. Pica Press, East Sussex.

Gerlach, J. (ed.) (1997) Seychelles Red Data Book - 1997. The Nature Protection Trust of Seychelles, Victoria, Mahé.

Grubb, P., Jones, T.S., Davies, A.G., Edberg, E., Starin, A.D. \& Hill, J.E. (1998) Mammals of Ghana, Sierra Leone and The Gambia. Trendrine Press, Zennor.

Hall, L. \& Richards, G. (2000) Flying Foxes. Fruit and Blossom Bats of Australia. University of New South Wales Press, Sydney.

Hanak, V., Benda, P. \& Hanzal, V. (1995) Review of bat distribution in the Czech Republic. Bulletin CESON, 5, 3-15.

Happold, D.C.D. (1987) The Mammals of Nigeria. Clarendon Press, Oxford.

Happold, D.C.D., Happold, M. \& Hill, J. E. (1987) The bats of Malawi. Mammalia, 51(3), 337-414.

Harris, S., Morris, P., Wray, S. \& Yalden, D. (1995) A Review of British Mammals: Population Estimates and Conservation Status of British Mammals other than Cetaceans. Joint Nature Conservation Committee, Peterborough.

Harrison, D.L. \& Bates, P.J.J. (1991) The Mammals of Arabia, 2nd edn. Harrison Zoological Museum, Sevenoaks.

Hayman, R.W. \& Hill, J. E. (1971) Order Chiroptera. In The Mammals of Africa. An Identification Manual. Part 2. (eds J. Meester \& H.W. Setzer), pp. 1-73. Smithsonian Institution Press, Washington DC.

Heaney, L.R., Gonzales, P.C. \& Alcala, A.C. (1987) An annotated checklist of the taxonomic and conservation status of land mammals in the Philippines. Siliman Journal, 34, 32-66.

Hensley, D. (1992) The James River bat cave. Bats, 10(2), 17.

Hill, J. E. (1971) The bats of Aldabra Atoll, western Indian Ocean. Philosophical Transactions of the Royal Society London B, 260, 573-576

Hill, J. E. (1985) Bats from the Bahamas. Scientific Exploration Society Newsletter, 16(1), 11-13.

Hill, J. E. (1988) A bat from the Falkland Islands. Bat News, 15,6 .

Hilton-Taylor, C. (compiler) (2000) 2000 IUCN Red List of Threatened Animals. IUCN, Gland and Cambridge.

Hsu, M.J. (1997) Population status and conservation of bats (Chiroptera) in Kenting National Park, Taiwan. Oryx, 31, 295-301.

Husson, A.M. (1960) De Zoogdieren van de Nederlanse Antillen [Mammals of the Netherlands Antilles]. Fauna Nederlandse Antillen, no. 2. 's-Gravenhage and Willemstad.

Husson, A.M. (1962) The bats of Suriname. Zoologische Verhandelingen, 58, 1-282.

Hutson, A.M., Mickleburgh, S. \& Mitchell-Jones, A.J. (1995) Bats Underground: A Conservation Code, 2nd edn. The Bat Conservation Trust, London.

Hutson, A.M., Mickleburgh, S.P. \& Racey, P.A. (compilers) (2001) Microchiropteran Bats: Global Status Survey and Conservation Action Plan. IUCN/SSC Chiroptera Specialist Group. IUCN, Gland, Switzerland, and Cambridge, UK.

Ingle, R.N. \& Heaney, L.R. (1992) A key to the bats of the Philippine Islands. Fieldiana: Zoology, New Series, 69, 1-44.

Isaksen, K., Syvertsen, P.O., van der Kooij, J. \& Rinden, H. (eds) (1998) Truete pattedye i Norge: faktaark og forslag til rodliste. Norsk Zoologisk Forening Rapport, 5, 1-182.

IUCN (1994) IUCN Red List Categories. Prepared by IUCN Species Survival Commission. IUCN, Gland, Switzerland.

Jackson, A.C. \& Fenton, M.B. (2001) Human rabies and bat bites. The Lancet, 357, 1714. 
Jones, G. \& Barrett, E. (1999) Case 3073. Vespertilio pipistrellus Schreber, 1774 and V. pygmaeus Leach, 1825 (Currently Pipistrellus pipistrellus and P.pygmaeus; Mammalia, Chiroptera): Proposed assignment of neotypes. Bulletin of Zoological Nomenclature, 56(3), 182-186.

Juste, J. \& Ibanez, C. (1993) Bats of the Gulf of Guinea islands: faunal composition and origins. Biodiversity and Conservation, 3(9), 837-850.

Karandinos, M. \& Paraschi, L. (1992) The Red Data Book of Threatened Vertebrates of Greece. Hellenic Zoological Society, Athens.

Khabilov, T.K. (1989) The bats of Tajikistan: their species composition, distribution and protection. In European Bat Research 1987 (eds V. Hanak, I. Horacek \& J. Gaisler), pp. 415-419. Charles University Press, Prague.

King, C.M. (ed.) (1995) The Handbook of New Zealand Mammals. Oxford University Press, Oxford.

Kingdon, J. (1974) East African Mammals. An Atlas of Evolution in Africa, Volume 2A (Insectivores and Bats). Academic Press, New York and London.

Klingener, D., Genoways, H.H. \& Baker, R.J. (1978) Bats from southern Haiti. Annals of the Carnegie Museum, 47, 81-99.

Koch-Weser, S. (1984) Fledermaüse aus Obervolta, W-Afrika. Senckenbergiana Biologica, 64(4/6), 255-311.

Kock, D. (1969) Die fledermaus-fauna des Sudan. Abhandlungen hrsg. von der Senckenbergischen Naturforschenden Gesellschaft, 521, 1-238.

Kock, D. (1981) Zur Chiropteren-fauna von Burundi (Mammalia). Senckenbergiana Biologica, 61(5/6), 329-336.

Koopman, K.F. (1975) Bats of the Sudan. Bulletin of the American Museum of Natural History, 154(4), 353-444.

Koopman, K.F. (1993) Order Chiroptera. In Mammal Species of the World (eds D.E. Wilson \& D.M. Reeder), pp. 137-232. Smithsonian Institution Press, Washington DC.

Koopman, K.F., Hecht, M.K. \& Lidecky-Janacek, E. (1957) Notes on the mammals of the Bahamas with special reference to bats. Journal of Mammalogy, 38, 164-174.

Koopman, K.F., Kofron, K.P. \& Chapman, A. (1995) The bats of Liberia: Systematics, ecology and distribution. American Museum Novitates, 3148, 1-24.

Kowalski, K. \& Rzebik-Kowalska, B. (1991) Mammals of Algeria. Zaklad Narodowy Imienia Ossolinskich Wydawnictwo Polskiej Akademii Nauk Wroclaw.

Krystufek, B. (1991) Sesalei Slovenije [Mammals of Slovenia]. Prirodosslovni musej Slovenije, Ljubljana.

Krystufek, B. \& Cerveny, J. (1997) New and noteworthy records of bats in Slovenia. Myotis, 35, 89-93.

Krystufek, B., Vohralik, V., Flousek, J. \& Petkowski, S. (1992) Bats (Mammalia: Chiroptera) of Macedonia, Yugoslavia. In Prague Studies in Mammalogy (eds I. Horacek \& V. Vohralik), pp. 93-111. Charles University Press, Prague.

Lekagul, B. \& McNeely, J.A. (1977) Mammals of Thailand. Kuruspha Ladprao Press, Bangkok.

Lewis, S.E. (1995) Roost fidelity of bats - a review. Journal of Mammalogy, 76, 481-496.

Lim, B.K., Engstrom, R.M., Anderson, R.P. \& Watson, L.C. (1999) First records of 10 species and comments on the diversity of bats in Iwokrama Forest. Acta Chiropterologica, 1(2), 179-190.

Limpens, H.J.G.A., Mostert, K. \& Bongers, W. (eds) (1997) Atlas van de Nederlandse Vleermuizen. KNNV Uitgeverij, Utrecht.

Linares, O.J. (1998) Mamíferos de Venezuela. Sociedad Conservacionista Audubon de Venezuela and BP Venezuela, Caracas.
Makin, D. \& Mendelssohn, H. (1987) The fruit-bat issue in Israel. Bat News, 11, 4-5.

Mallon, D.P. (1985) The mammals of the Mongolian People's Republic. Mammal Review, 15(2), 71-102.

Marinho-Filho, J. \& Sazima, I. (1998) Brazilian bats and conservation biology: a first survey. In Bat Biology and Conservation (eds T.H. Kunz \& P.A. Racey), pp. 282-294. Smithsonian Institution Press, Washington DC.

McCarthy, T.J., Davis, W.B., Hill, J. E., Knox Jones Jr., J. \& Cruz, G.A. (1993) Bat (Mammalia: Chiroptera) records, early collectors, and faunal lists for northern Central America. Annals of the Carnegie Museum, 62(3), 191-228.

McCracken, G.F. (1986) Why are we losing our Mexican freetailed bats? Bats, 3(3), 1-4.

McFarlane, D.A. (1991) The species-genus relationship in Antillean bat communities. Mammalia, 55(3), 363-370.

McGinn, A.P. (2001) Malaria's lethal grip tightens. In Vital Signs 2001-2002. The Trends that are Shaping our Future, pp. 134-135. Earthscan Publications Ltd., London.

McWilliam, A.N. (1994) Nocturnal animals. In DDT in the Tropics. The Impact on Wildlife in Zimbabwe of Ground-spraying for Tsetse Fly Control (eds J.R. Douthwaite \& C.C.D. Tingle), pp. 103-133. Natural Resources Institute, Chatham.

Medellín, R.A., Arita, H.T. \& Sanchez, O. (1997) Identificación de los Murciélagos de México. Clave de Campo. Asociación Mexicana de Mastozoología, A.C. Publicaciones Especiales Núm. 2. Mexico City.

Mendelssohn, H. \& Yom-Tov, Y. (1999) Mammalia of Israel: Fauna Palestina. The Israel Academy of Sciences and Humanities.

Mickleburgh, S.P., Hutson, A.M. \& Racey, P.A. (eds) (1992) Old World Fruit Bats. An Action Plan for their Conservation. IUCN/SSC Chiroptera Specialist Group. IUCN, Gland, Switzerland.

Mitchell-Jones, A.J., Amori, G., Bogdanowicz, W., Krystufek, B., Reijnders, P.J.H., Spitzenberger, F., Stubbe, M., Thissen, J.B.M., Vohralik, V. \& Zima, J. (1999) The Atlas of European Mammals. T \& AD Poyser Natural History, London.

Moeschler, P. (1991) Concept national pour la protection et l'Etude des chauves-souris. Publications Speciale de Rhinolophe, 1, 1-102.

Murphy, M. (1987) India's Samanar Hill caves saved. Bats, $5(3), 6$.

National Caving Association (1997) Cave Conservation Handbook. National Caving Association, London.

O'Sullivan, P. (1994) Bats in Ireland. Irish Naturalists Journal, Special Zoological Supplement.

Pacheco, V., de Macedo, H., Vivar, E., Ascorra, C., AranaCardó, R. \& Solari, S. (1995) Lista Anotada de los Mamíferos Peruanos. Occasional Papers in Conservation Biology, Number 2. Conservation International, Washington DC.

Palmeirim, J.M. (1989) Status of bats in Portugal. In European Bat Research 1987 (eds V. Hanak, I. Horacek \& J. Gaisler), pp. 373-379. Charles University Press, Prague.

Paunovic, M., Paunovic, A. \& Ivovic, M. (1998) Mehely's horseshoe bat Rhinolophus mehelyi Matschie, 1901 - New to the Yugoslavian bat fauna. Myotis, 36, 115-119.

Pauza, D.H. \& Panziene, N. (1998) Bats of Lithuania: distribution, status and protection. Mammal Review, 28, 53-67.

Payne, J., Francis, C.M. \& Phillipps, K. (1985) A Field Guide to the Mammals of Borneo. Sabah Society and WWF Malaysia, Kuala Lumpur. 
Pearch, M.J., Bates, P.J.J. \& Magin, C. In press. A review of the small mammal fauna of Djibouti and the results of a recent survey. Mammalia.

Petersen, A. (1994) Leurblökur á Íslandi. Náttúrufræðingurinn, 64(1), 3-12. [In Icelandic].

Peterson, R.L., Eger, J.L. \& Mitchell, L. (1995) Chiroptères. Faune de Madagascar, 84, 1-204.

Phillips, W.R. (1990) Priorities for Ghost Bat (Macroderma gigas) Conservation and Management. Australian National Parks and Wildlife Service, Canberra.

Pierson, E.D. (1998) Tall trees, deep holes, and scarred landscapes: conservation biology of North American bats. In Bat Biology and Conservation (eds T.H. Kunz \& P.A. Racey), pp. 309-325. Smithsonian Institution Press, Washington DC.

Pierson, E.D. \& Rainey, W.E. (1992) The biology of flying foxes of the genus Pteropus: a review. In Pacific Island Flying Foxes: Proceedings of an International Conservation Conference (eds D.E. Wilson \& G.L. Graham), pp. 1-17. US Fish and Wildlife Service Biological Report 90(23). US Department of the Interior, Fish and Wildlife Service, Washington DC.

Pint, J.J. (1994) Who cares about Mexican bats? National Speleological Society News, 52(3), 94.

Qumsiyeh, M.B. (1985) The bats of Egypt. Special Publications. Museum. Texas Tech University, 23, 1-102.

Qumsiyeh, M.B. \& Schlitter, D.A. (1982) The bat fauna of Jabal Al Akhdar, north-east Libya. Annals of the Carnegie Museum, 51, 377-389.

Rainey, W.E. (1998) Conservation of bats on remote IndoPacific islands. In Bat Biology and Conservation (eds T.H. Kunz \& P.A. Racey), pp. 326-341. Smithsonian Insitution Press, Washington DC.

Rakhmatulina, I.K. (1989) The peculiarity of the bat fauna of Azerbaijan. In European Bat Research 1987 (eds V. Hanak, I. Horacek \& J. Gaisler), pp. 409-414. Charles University Press, Prague.

Rakhmatulina, I.K. (1996a) The bat fauna of the Caucasus and problems of its study. Myotis, 34, 51-57.

Rakhmatulina, I.K. (1996b) On the history of study and tendency of changes of the eastern transcaucasian bat fauna. Myotis, 34, 59-70.

Redford, K.H. \& Eisenberg, J.F. (1992) Mammals of the Neotropics. Volume 2. The Southern Cone. The University of Chicago Press, Chicago and London.

Reid, F. (1997) A Field Guide to the Mammals of Southeast Mexico and Central America. Oxford University Press, Oxford.

Robbins, C.B. (1980) Small mammals of Togo and Benin. I. Chiroptera. Mammalia, 44(1), 83-88.

Rodriguez-Duran, A. \& Kunz, T.H. (2001) Bats of the West Indies. CRC Press.

Rodriguez-H., B. \& Wilson, D.E. (1999) Lista y Distribución de las Especies de Murciélagos de Costa Rica. Occasional Papers in Conservation Biology Number 5. Conservation International, Washington DC.

Rodríguez-Mahecha, J.V., Hernández-Camacho, J.I., Defler, T.R., Alberico, M., Mast, R.B., Mittermeier, R.A. \& Cadena, A. (1995) Mamíferos Colombianos: Sus Nombres Comunes e Indígenas. Occasional Papers in Conservation Biology Number 3. Conservation International, Washington DC.

Rybin, S.N., Horacek, I. \& Cerveny, J. (1989) The bats of southern Kirghizia: distribution and faunal status. In European Bat Research 1987 (eds V. Hanak, I. Horacek \& J. Gaisler), pp. 421-441. Charles University Press, Prague.
Sankaran, R. (2001) The status and conservation of the Ediblenest swiftlet (Collocalia fuciphaga) in the Andaman and Nicobar Islands. Biological Conservation, 97, 283-294.

Savic, I.R., Paunovic, M., Milenkovic, M. \& Stamenkovic, S. (1995) Diversity of mammal fauna of Yugoslavia, with review of the species of international importance. In Biodiversity of Yugoslavia with Review of Species of International Importance (eds V. Stevanovic \& V. Vasic). Biological Faculty and Ecolibri, Belgrade. [In Serbian].

Schlitter, D.A., Robbins, L.W. \& Buchanan, S.A. (1983) Bats of the Central African Republic (Mammalia: Chiroptera). Annals of the Carnegie Museum, 51(8), 133-155.

Silva-Taboada, G. (1978) Los Murcielágos de Cuba. Editorial Academia, Havana.

Simmons, N.B., Voss, R.S. \& Pecham, H.C. (2000) The bat fauna of the Saül region, French Guiana. Acta Chiropterologica, 2(1), 23-36.

Skinner, J.D. \& Smithers, R.H.N. (1990) Mammals of the Southern African Subregion, 2nd edn. University of Pretoria Press, Pretoria.

Smith, P.G. \& Kerry, S.M. (1996) The Iwokrama Rain Forest Programme for sustainable development: how much of Guyana's bat (Chiroptera) diversity does it encompass? Biodiversity and Conservation, 5, 921-942.

Stebbings, R.E. (1988) Conservation of European Bats. Christopher Helm, London.

Taylor, P.J. (2000) Bats of Southern Africa; Guide to Biology, Identification and Conservation. University of Natal Press, Pietermartizburg.

Tuttle, M.D. \& Taylor, D.A.R. (1998) Bats and Mines. Revised edition. Resource Publication Number 3, Bat Conservation International, Austin.

Vaughan, N. \& Hill, J.E. (1996) Bat (Chiroptera) diversity and abundance in banana plantations and rain forest, and three new records for St. Vincent, Lesser Antilles. Mammalia, 60(3), 441-447.

Verboom, B. (1998) The Use of Edge Habitats by Commuting and Foraging Bats. IBN Scientific Contributions 10. DLO Institute for Forestry and Nature Research (IBN-DLO), Wageningen.

Vernier, E. (1997) Manuale Pratico dei Chirotteri Italiana, 2nd edn. Società Cooperativa Tipografica, Padova.

Vielliard, J. (1974) Les Cheiroptères du Tchad. Revue Suisse de Zoologie, 81(4), 975-991.

Watson, J., Hamilton-Smith, E., Gillieson, D. \& Kiernan, K. (eds) (1997) Guidelines for Cave and Karst Protection. IUCN, Gland and Cambridge.

Wiles, G.J. (1992) Recent trends in the fruit bat trade on Guam. In Pacific Island Flying Foxes: Proceedings of an International Conservation Conference (eds D.E. Wilson \& G.L. Graham), pp. 53-60. US Fish and Wildlife Service Biological Report 90(23). US Department of the Interior, Fish and Wildlife Service, Washington DC.

Wiles, G.J. (1994) The Pacfic flying fox trade: A new dilemma. Bats, 12(3), 15-18.

Worthington, D.J. \& Taisacan, E.M. (1996) Fruit Bat Research: 1995 Annual Report. Division of Fish and Wildlife, Saipan, Commonwealth of the Northern Mariana Islands.

Yoshiyuki, M. (1989) A Systematic Study of the Japanese Chiroptera. National Science Museum, Tokyo.

Zhang Yongzu (1997) Distribution of Mammalian Species in China. China Forestry Publishing House, Beijing.

van Zyll de Jong, C.G. (1985) Handbook of Canadian Mammals. National Museum of Natural Sciences, Ottawa. 


\section{Biographical sketches}

Simon Mickleburgh graduated with a BSc in Biological Sciences from the University of London and an MSc in Ecology from the University College of North Wales. He worked initially on the conservation of the chough Pyrrhocorax pyrrhocorax in Britain and on amphibian conservation issues in Central Wales before joining Fauna \& Flora International (FFI) as London Bat Officer in 1984. Since that time he has concentrated on bat conservation projects at both a national and international level, particularly the production and implementation of Action Plans. He is currently Senior Conservation Researcher at FFI and is Manager of FFI's grant-giving programme, the $100 \%$ Fund.

Tony Hutson worked at the British Museum (Natural History) on insects, especially ectoparasites of bats. In 1984, he joined FFI to establish a bat conservation programme.

\section{Appendix}

Number of bat species, IUCN Red List species and endemic species for countries of the world.

IUCN Red List species. These are species listed in the 2000 IUCN Red List of Threatened Species (Hilton-Taylor, 2000) $\mathrm{CR}=$ Critically Endangered, $\mathrm{EN}=$ Endangered, $\mathrm{VU}=$ Vulnerable, LRcd = Lower Risk: Conservation Dependent, LRnt = Lower Risk: Near Threatened, EX=Extinct, $\mathrm{DD}=$ Data Deficient.
When The Bat Conservation Trust was set up in 1991, he became the first Conservation Officer. In 2000, he left to be come a freelance consultant biologist, specialising in bats at an international level. He has been Co-Chairman of the IUCN-SSC Chiroptera Specialist Group since 1986. He has been involved in running field projects around the world and in the development and implementation of bat conservation initiatives and research at home and abroad.

Paul Racey graduated from the University of Cambridge with a degree in Zoology and carried out his PhD work on the reproductive biology of bats at the Zoological Society of London. Since moving to Aberdeen in 1973 he has worked on the ecology and conservation biology of bats, initially at temperate latitudes but more recently in the tropics, particularly Madagascar. He was founding Chairman of The Bat Conservation Trust, is Co-Chair of IUCN's Chiroptera Specialist Group and chairs the Conservation Committee of FFI.

Endemics. Total number of species recorded only from that country.

Total species. The total number of bat species recorded from that country. Mega = bats in Suborder Megachiroptera, Micro = bats in Suborder Microchiroptera. Sources for these figures are given and included in the reference list. For many countries, detailed and up to date lists are not available and it is likely that these figures will change as more research is undertaken.

\begin{tabular}{|c|c|c|c|c|c|c|c|c|c|c|c|c|c|}
\hline \multirow[b]{2}{*}{ Country } & \multicolumn{8}{|c|}{ IUCN Red List species } & \multirow{2}{*}{$\begin{array}{l}\text { Total } \\
\text { endemics }\end{array}$} & \multicolumn{4}{|c|}{ Total species } \\
\hline & CR & EN & VU & LRcd & LRnt & EX & DD & Total & & Mega & Micro & Total & Source \\
\hline Afghanistan & 0 & 0 & 5 & 0 & 6 & 0 & 0 & 11 & 0 & 0 & 37 & 37 & (1) \\
\hline Albania & 0 & 0 & 2 & 0 & 4 & 0 & 0 & 6 & 0 & 0 & 24 & 24 & (2) \\
\hline Algeria & 0 & 0 & 4 & 0 & 4 & 0 & 0 & 8 & 0 & 0 & 26 & 26 & (3) \\
\hline Am. Samoa & 0 & 1 & 0 & 0 & 0 & 0 & 1 & 2 & 0 & 2 & 2 & 4 & (4) \\
\hline Am. Virgin Is. & 0 & 0 & 1 & 0 & 0 & 0 & 0 & 1 & 0 & 0 & 5 & 5 & (5) \\
\hline Andorra & 0 & 0 & 3 & 0 & 2 & 0 & 0 & 5 & 0 & 0 & 11 & 11 & (6) \\
\hline Angola & 0 & 0 & 3 & 0 & 6 & 0 & 2 & 11 & 0 & 15 & 43 & 58 & (7) \\
\hline Anguilla & 0 & 0 & 0 & 0 & 1 & 0 & 0 & 1 & 0 & 0 & 5 & 5 & (8) \\
\hline Antigua and Barbuda & 0 & 0 & 0 & 0 & 2 & 0 & 0 & 2 & 0 & 0 & 7 & 7 & (9) \\
\hline Argentina & 0 & 0 & 3 & 0 & 7 & 0 & 0 & 10 & 1 & 0 & 57 & 57 & (10) \\
\hline Armenia & 0 & 1 & 5 & 0 & 5 & 0 & 0 & 11 & 0 & 0 & 24 & 24 & (11) \\
\hline Aruba & 0 & 0 & 1 & 0 & 0 & 0 & 0 & 1 & 0 & 0 & 4 & 4 & (12) \\
\hline Australia & 1 & 0 & 7 & 0 & 14 & 1 & 1 & 24 & 15 & 12 & 63 & 75 & (13) \\
\hline Austria & 0 & 0 & 4 & 0 & 4 & 0 & 0 & 8 & 0 & 0 & 24 & 24 & (14) \\
\hline Azerbaijan & 0 & 0 & 6 & 0 & 5 & 0 & 0 & 11 & 0 & 0 & 27 & 27 & (15) \\
\hline Bahamas & 0 & 0 & 1 & 0 & 3 & 0 & 0 & 4 & 1 & 0 & 12 & 12 & (16) \\
\hline Bahrain & 0 & 0 & 0 & 0 & 0 & 0 & 0 & 0 & 0 & 0 & 4 & 4 & (17) \\
\hline Bangladesh & 0 & 0 & 0 & 0 & 0 & 0 & 0 & 0 & 0 & 3 & 15 & 18 & (18) \\
\hline Barbados & 0 & 0 & 0 & 0 & 2 & 0 & 0 & 2 & 0 & 0 & 6 & 6 & (19) \\
\hline Belarus & 0 & 0 & 3 & 0 & 3 & 0 & 0 & 6 & 0 & 0 & 17 & 17 & (20) \\
\hline Belgium & 0 & 0 & 3 & 0 & 5 & 0 & 0 & 8 & 0 & 0 & 18 & 18 & (21) \\
\hline Belize & 0 & 0 & 1 & 0 & 8 & 0 & 0 & 9 & 0 & 0 & 69 & 69 & (22) \\
\hline Benin & 0 & 0 & 1 & 0 & 0 & 0 & 0 & 1 & 0 & 4 & 28 & 32 & (23) \\
\hline Bermuda & 0 & 0 & 0 & 0 & 0 & 0 & 0 & 0 & 0 & 0 & 4 & 4 & (24) \\
\hline Bhutan & 0 & 0 & 0 & 0 & 0 & 0 & 0 & 0 & 0 & 3 & 2 & 5 & (25) \\
\hline
\end{tabular}




\begin{tabular}{|c|c|c|c|c|c|c|c|c|c|c|c|c|c|}
\hline \multirow[b]{2}{*}{ Country } & \multicolumn{8}{|c|}{ IUCN Red List species } & \multirow{2}{*}{$\begin{array}{l}\text { Total } \\
\text { endemics }\end{array}$} & \multicolumn{4}{|c|}{ Total species } \\
\hline & CR & EN & $\mathrm{VU}$ & LRcd & LRnt & EX & $\mathrm{DD}$ & Total & & Mega & Micro & Total & Source \\
\hline Bolivia & 0 & 0 & 1 & 0 & 9 & 0 & 0 & 10 & 0 & 0 & 107 & 107 & (26) \\
\hline Bosnia & 0 & 0 & 7 & 0 & 4 & 0 & 0 & 11 & 0 & 0 & 22 & 22 & (27) \\
\hline Botswana & 0 & 0 & 0 & 0 & 5 & 0 & 1 & 6 & 0 & 3 & 31 & 34 & (28) \\
\hline Brazil & 0 & 0 & 14 & 0 & 23 & 0 & 3 & 40 & 6 & 0 & 137 & 137 & (29) \\
\hline Br. Virgin Is. & 0 & 0 & 0 & 0 & 0 & 0 & 0 & 0 & 0 & 0 & 3 & 3 & (30) \\
\hline Brunei & 0 & 0 & 0 & 0 & 1 & 0 & 0 & 1 & 0 & 11 & 11 & 22 & (31) \\
\hline Bulgaria & 0 & 0 & 7 & 0 & 6 & 0 & 0 & 13 & 0 & 0 & 29 & 29 & (32) \\
\hline Burkina Faso & 0 & 0 & 0 & 0 & 2 & 0 & 0 & 2 & 0 & 5 & 28 & 33 & (33) \\
\hline Burundi & 0 & 0 & 0 & 0 & 0 & 0 & 1 & 1 & 0 & 6 & 18 & 24 & (34) \\
\hline Cambodia & 0 & 0 & 0 & 0 & 2 & 0 & 0 & 2 & 0 & 10 & 28 & 38 & (35) \\
\hline Cameroon & 0 & 0 & 2 & 0 & 16 & 0 & 0 & 18 & 0 & 14 & 57 & 71 & (36) \\
\hline Canada & 0 & 0 & 1 & 0 & 0 & 0 & 0 & 1 & 0 & 0 & 20 & 20 & (37) \\
\hline Cape Verde Is. & 0 & 0 & 0 & 0 & 0 & 0 & 0 & 0 & 0 & 0 & 2 & 2 & (38) \\
\hline Cayman Is. & 0 & 0 & 0 & 0 & 3 & 0 & 0 & 3 & 0 & 0 & 8 & 8 & (39) \\
\hline C.A.R. (1) & 0 & 0 & 1 & 0 & 1 & 0 & 0 & 2 & 0 & 13 & 32 & 45 & $(40)$ \\
\hline Chad & 0 & 0 & 1 & 0 & 0 & 0 & 0 & 1 & 0 & 3 & 18 & 21 & (41) \\
\hline Chile & 0 & 0 & 3 & 0 & 3 & 0 & 0 & 6 & 0 & 0 & 10 & 10 & (42) \\
\hline China & 0 & 0 & 2 & 0 & 20 & 0 & 3 & 25 & 6 & 8 & 82 & 90 & (43) \\
\hline Colombia & 0 & 1 & 10 & 0 & 33 & 0 & 0 & 44 & 2 & 0 & 170 & 170 & (44) \\
\hline C.N.M.I. (2) & 0 & 1 & 0 & 0 & 0 & 0 & 0 & 1 & 0 & 1 & 1 & 2 & (45) \\
\hline Comoros & 0 & 0 & 0 & 0 & 2 & 0 & 0 & 2 & 0 & 3 & 2 & 5 & (46) \\
\hline Congo Rep. & 0 & 0 & 1 & 0 & 7 & 0 & 1 & 9 & 1 & 12 & 36 & 48 & $(47)$ \\
\hline Cook Islands & 0 & 0 & 0 & 0 & 0 & 0 & 0 & 0 & 0 & 1 & 0 & 1 & (48) \\
\hline Costa Rica & 0 & 0 & 2 & 0 & 11 & 0 & 0 & 13 & 0 & 0 & 107 & 107 & (49) \\
\hline Côte d'Ivoire & 0 & 0 & 3 & 0 & 4 & 0 & 1 & 8 & 0 & 12 & 60 & 72 & (50) \\
\hline Croatia & 0 & 0 & 7 & 0 & 4 & 0 & 0 & 11 & 0 & 0 & 28 & 28 & (51) \\
\hline Cuba & 0 & 0 & 2 & 0 & 7 & 0 & 0 & 9 & 1 & 0 & 27 & 27 & (52) \\
\hline Cyprus & 0 & 0 & 1 & 0 & 3 & 0 & 0 & 4 & 0 & 1 & 15 & 16 & (53) \\
\hline Czech Rep. & 0 & 0 & 5 & 0 & 3 & 0 & 0 & 8 & 0 & 0 & 21 & 21 & (54) \\
\hline D.R.C. (3) & 2 & 0 & 5 & 0 & 25 & 0 & 1 & 33 & 2 & 17 & 78 & 95 & (55) \\
\hline Denmark & 0 & 0 & 2 & 0 & 0 & 0 & 0 & 2 & 0 & 0 & 15 & 15 & (56) \\
\hline Djibouti & 0 & 0 & 1 & 0 & 1 & 0 & 0 & 2 & 0 & 0 & 17 & 17 & (57) \\
\hline Dominica & 0 & 0 & 1 & 0 & 3 & 0 & 0 & 4 & 0 & 0 & 12 & 12 & (58) \\
\hline Dominican Rep. & 0 & 0 & 0 & 0 & 6 & 0 & 0 & 6 & 0 & 0 & 18 & 18 & (59) \\
\hline Ecuador & 0 & 1 & 7 & 0 & 12 & 0 & 0 & 20 & 1 & 0 & 125 & 125 & (60) \\
\hline Egypt & 0 & 0 & 4 & 0 & 1 & 0 & 0 & 5 & 0 & 1 & 21 & 22 & (61) \\
\hline El Salvador & 0 & 0 & 2 & 0 & 6 & 0 & 1 & 9 & 0 & 0 & 58 & 58 & (62) \\
\hline Eq. Guinea & 0 & 0 & 1 & 0 & 8 & 0 & 0 & 9 & 0 & 9 & 39 & 48 & (63) \\
\hline Eritrea & 0 & 0 & 2 & 0 & 0 & 0 & 0 & 2 & 0 & 0 & 11 & 11 & (64) \\
\hline Estonia & 0 & 0 & 1 & 0 & 0 & 0 & 0 & 1 & 0 & 0 & 11 & 11 & (65) \\
\hline Ethiopia & 0 & 0 & 7 & 0 & 12 & 0 & 1 & 20 & 1 & 8 & 58 & 66 & (66) \\
\hline Falkland Is. (4) & 0 & 0 & 0 & 0 & 0 & 0 & 0 & 0 & 0 & 0 & 0 & 0 & (67) \\
\hline F.S M. (5) & 0 & 1 & 0 & 0 & 0 & 0 & 0 & 1 & 0 & 4 & 1 & 5 & (68) \\
\hline Fiji & 0 & 1 & 0 & 0 & 1 & 0 & 0 & 2 & 0 & 4 & 2 & 6 & (69) \\
\hline Finland & 0 & 0 & 0 & 0 & 0 & 0 & 0 & 0 & 0 & 0 & 8 & 8 & (70) \\
\hline France & 0 & 0 & 8 & 0 & 5 & 0 & 0 & 13 & 0 & 0 & 29 & 29 & (71) \\
\hline French Guiana & 0 & 0 & 2 & 0 & 8 & 0 & 2 & 12 & 0 & 0 & 102 & 102 & (72) \\
\hline Gabon & 0 & 0 & 1 & 0 & 5 & 0 & 0 & 6 & 0 & 9 & 23 & 32 & (73) \\
\hline Gambia & 0 & 0 & 0 & 0 & 1 & 0 & 0 & 1 & 0 & 4 & 23 & 27 & (74) \\
\hline Georgia & 0 & 0 & 6 & 0 & 4 & 0 & 0 & 10 & 0 & 0 & 25 & 25 & (75) \\
\hline Germany & 0 & 0 & 5 & 0 & 4 & 0 & 0 & 9 & 0 & 0 & 23 & 23 & (76) \\
\hline Ghana & 0 & 0 & 2 & 0 & 16 & 0 & 1 & 19 & 0 & 13 & 71 & 84 & (77) \\
\hline Gibraltar & 0 & 0 & 0 & 0 & 1 & 0 & 0 & 1 & 0 & 0 & 4 & 4 & (78) \\
\hline Greece & 0 & 0 & 5 & 0 & 6 & 0 & 0 & 11 & 0 & 0 & 28 & 28 & (79) \\
\hline Grenada & 0 & 0 & 0 & 0 & 0 & 0 & 0 & 0 & 0 & 0 & 13 & 13 & (80) \\
\hline Guadeloupe & 0 & 1 & 3 & 0 & 3 & 0 & 0 & 7 & 2 & 0 & 12 & 12 & (81) \\
\hline Guam & 0 & 1 & 0 & 0 & 0 & 0 & 0 & 1 & 0 & 1 & 1 & 2 & (82) \\
\hline Guatemala & 1 & 1 & 1 & 0 & 11 & 0 & 0 & 14 & 1 & 0 & 94 & 94 & (83) \\
\hline Guinea & 0 & 0 & 1 & 0 & 6 & 0 & 1 & 8 & 1 & 9 & 37 & 46 & (84) \\
\hline
\end{tabular}




\begin{tabular}{|c|c|c|c|c|c|c|c|c|c|c|c|c|c|}
\hline \multirow[b]{2}{*}{ Country } & \multicolumn{8}{|c|}{ IUCN Red List species } & \multirow{2}{*}{$\begin{array}{l}\text { Total } \\
\text { endemics }\end{array}$} & \multicolumn{4}{|c|}{ Total species } \\
\hline & $\mathrm{CR}$ & EN & VU & LRcd & LRnt & EX & DD & Total & & Mega & Micro & Total & Source \\
\hline Guinea-Bissau & 0 & 0 & 0 & 0 & 5 & 0 & 0 & 5 & 0 & 7 & 28 & 35 & (85) \\
\hline Guyana & 0 & 0 & 3 & 0 & 10 & 0 & 2 & 15 & 0 & 0 & 107 & 107 & (86) \\
\hline Haiti & 0 & 0 & 0 & 0 & 6 & 0 & 0 & 6 & 0 & 0 & 17 & 17 & (87) \\
\hline Honduras & 0 & 0 & 3 & 0 & 12 & 0 & 1 & 16 & 0 & 0 & 98 & 98 & (88) \\
\hline Hungary & 0 & 1 & 6 & 0 & 5 & 0 & 0 & 12 & 0 & 0 & 26 & 26 & (89) \\
\hline Iceland (6) & 0 & 0 & 0 & 0 & 0 & 0 & 0 & 0 & 0 & 0 & 0 & 0 & (90) \\
\hline India & 1 & 1 & 6 & 0 & 15 & 0 & 5 & 28 & 9 & 13 & 96 & 109 & (91) \\
\hline Indonesia & 0 & 4 & 14 & 0 & 25 & 0 & 4 & 47 & 24 & 63 & 112 & 175 & (92) \\
\hline Iran & 0 & 1 & 7 & 0 & 5 & 0 & 0 & 13 & 0 & 1 & 37 & 38 & (93) \\
\hline Iraq & 0 & 0 & 5 & 0 & 2 & 0 & 0 & 7 & 0 & 0 & 19 & 19 & (94) \\
\hline Ireland & 0 & 0 & 1 & 0 & 1 & 0 & 0 & 2 & 0 & 0 & 7 & 7 & (95) \\
\hline Israel & 0 & 0 & 6 & 0 & 5 & 0 & 0 & 11 & 0 & 1 & 32 & 33 & (96) \\
\hline Italy & 0 & 0 & 7 & 0 & 6 & 0 & 0 & 13 & 0 & 0 & 30 & 30 & (97) \\
\hline Jamaica & 0 & 1 & 2 & 0 & 5 & 0 & 0 & 8 & 2 & 0 & 21 & 21 & (98) \\
\hline Japan & 1 & 5 & 3 & 0 & 8 & 0 & 2 & 19 & 12 & 3 & 36 & 39 & (99) \\
\hline Jordan & 0 & 0 & 5 & 0 & 4 & 0 & 0 & 9 & 0 & 0 & 14 & 14 & (102) \\
\hline Kazakhstan & 0 & 0 & 3 & 0 & 3 & 0 & 0 & 6 & 0 & 0 & 27 & 27 & (101) \\
\hline Kenya & 0 & 0 & 5 & 0 & 17 & 0 & 2 & 24 & 1 & 11 & 84 & 95 & (102) \\
\hline Kuwait & 0 & 0 & 0 & 0 & 0 & 0 & 0 & 0 & 0 & 0 & 1 & 1 & (103) \\
\hline Kyrgyzstan & 0 & 0 & 2 & 0 & 1 & 0 & 0 & 3 & 0 & 0 & 16 & 16 & (104) \\
\hline Laos & 0 & 0 & 1 & 0 & 18 & 0 & 2 & 21 & 0 & 8 & 82 & 90 & (105) \\
\hline Latvia & 0 & 0 & 2 & 0 & 1 & 0 & 0 & 3 & 0 & 0 & 15 & 15 & (106) \\
\hline Lebanon & 0 & 0 & 4 & 0 & 3 & 0 & 0 & 7 & 0 & 1 & 15 & 16 & (107) \\
\hline Lesotho & 0 & 0 & 0 & 0 & 0 & 0 & 0 & 0 & 0 & 2 & 6 & 8 & (108) \\
\hline Liberia & 0 & 0 & 2 & 0 & 8 & 0 & 1 & 11 & 0 & 11 & 57 & 68 & (109) \\
\hline Libya & 0 & 0 & 1 & 0 & 2 & 0 & 0 & 3 & 0 & 0 & 14 & 14 & (110) \\
\hline Liechtenstein & 0 & 0 & 3 & 0 & 3 & 0 & 0 & 6 & 0 & 0 & 18 & 18 & (111) \\
\hline Lithuania & 0 & 0 & 2 & 0 & 1 & 0 & 0 & 3 & 0 & 0 & 17 & 17 & (112) \\
\hline Luxembourg & 0 & 0 & 3 & 0 & 3 & 0 & 0 & 6 & 0 & 0 & 17 & 17 & (113) \\
\hline Macedonia & 0 & 0 & 7 & 0 & 4 & 0 & 0 & 11 & 0 & 0 & 23 & 23 & (114) \\
\hline Madagascar & 1 & 0 & 6 & 0 & 7 & 0 & 8 & 22 & 14 & 3 & 25 & 28 & (115) \\
\hline Malawi & 0 & 0 & 0 & 0 & 8 & 0 & 1 & 9 & 0 & 6 & 51 & 57 & (116) \\
\hline Malaysia & 2 & 1 & 3 & 0 & 22 & 0 & 3 & 31 & 11 & 17 & 95 & 112 & (117) \\
\hline Maldives & 0 & 0 & 0 & 0 & 0 & 0 & 0 & 0 & 0 & 2 & 0 & 2 & (118) \\
\hline Mali & 0 & 0 & 0 & 0 & 3 & 0 & 0 & 3 & 0 & 3 & 15 & 18 & (119) \\
\hline Malta & 0 & 0 & 1 & 0 & 3 & 0 & 0 & 4 & 0 & 0 & 10 & 10 & (120) \\
\hline Martinique & 0 & 0 & 0 & 0 & 4 & 0 & 0 & 4 & 0 & 0 & 10 & 10 & (121) \\
\hline Mauritania & 0 & 0 & 0 & 0 & 0 & 0 & 0 & 0 & 0 & 5 & 40 & 45 & (122) \\
\hline Mauritius & 0 & 0 & 1 & 0 & 0 & 0 & 0 & 1 & 0 & 1 & 2 & 3 & (123) \\
\hline Mayotte & 0 & 0 & 0 & 0 & 0 & 0 & 0 & 0 & 0 & 1 & 1 & 2 & (124) \\
\hline Mexico & 1 & 4 & 9 & 0 & 17 & 0 & 0 & 31 & 13 & 0 & 137 & 137 & (125) \\
\hline Moldova & 0 & 0 & 4 & 0 & 3 & 0 & 0 & 7 & 0 & 0 & 20 & 20 & (126) \\
\hline Monaco & 0 & 0 & 0 & 0 & 0 & 0 & 0 & 0 & 0 & 0 & 5 & 5 & (127) \\
\hline Mongolia & 0 & 0 & 0 & 0 & 0 & 0 & 0 & 0 & 0 & 0 & 12 & 12 & (128) \\
\hline Montserrat & 0 & 1 & 0 & 0 & 3 & 0 & 0 & 4 & 0 & 0 & 10 & 10 & (129) \\
\hline Morocco & 0 & 0 & 6 & 0 & 4 & 0 & 0 & 10 & 0 & 0 & 26 & 26 & (130) \\
\hline Mozambique & 1 & 0 & 0 & 0 & 7 & 0 & 1 & 9 & 1 & 5 & 40 & 45 & (131) \\
\hline Myanmar & 2 & 0 & 0 & 0 & 16 & 0 & 3 & 21 & 3 & 12 & 76 & 88 & (132) \\
\hline Namibia & 0 & 1 & 1 & 0 & 3 & 0 & 1 & 6 & 1 & 2 & 24 & 26 & (133) \\
\hline Nepal & 0 & 0 & 2 & 0 & 7 & 0 & 3 & 12 & 1 & 4 & 47 & 51 & (134) \\
\hline Netherlands & 0 & 0 & 4 & 0 & 3 & 0 & 0 & 7 & 0 & 0 & 19 & 19 & (135) \\
\hline Neth. Antilles & 0 & 0 & 1 & 0 & 3 & 0 & 0 & 4 & 0 & 0 & 10 & 10 & (136) \\
\hline New Caledonia & 0 & 2 & 0 & 0 & 0 & 1 & 0 & 3 & 2 & 4 & 4 & 8 & (137) \\
\hline New Zealand & 0 & 0 & 2 & 0 & 0 & 1 & 0 & 3 & 3 & 0 & 3 & 3 & (138) \\
\hline Nicaragua & 0 & 0 & 1 & 0 & 11 & 0 & 1 & 13 & 0 & 0 & 88 & 88 & (139) \\
\hline Niger & 0 & 0 & 0 & 0 & 0 & 0 & 0 & 0 & 0 & 2 & 19 & 21 & (140) \\
\hline Nigeria & 0 & 0 & 2 & 0 & 11 & 0 & 0 & 13 & 0 & 12 & 59 & 71 & (141) \\
\hline Niue & 0 & 0 & 0 & 0 & 0 & 0 & 0 & 0 & 0 & 1 & 0 & 1 & (142) \\
\hline North Korea & 0 & 1 & 0 & 0 & 6 & 0 & 1 & 8 & 0 & 0 & 21 & 21 & (143) \\
\hline
\end{tabular}




\begin{tabular}{|c|c|c|c|c|c|c|c|c|c|c|c|c|c|}
\hline \multirow[b]{2}{*}{ Country } & \multicolumn{8}{|c|}{ IUCN Red List species } & \multirow{2}{*}{$\begin{array}{l}\text { Total } \\
\text { endemics }\end{array}$} & \multicolumn{4}{|c|}{ Total species } \\
\hline & CR & EN & VU & LRcd & LRnt & EX & $\mathrm{DD}$ & Total & & Mega & Micro & Total & Source \\
\hline Norway & 0 & 0 & 1 & 0 & 0 & 0 & 0 & 1 & 0 & 0 & 11 & 11 & (144) \\
\hline Oman & 0 & 0 & 3 & 0 & 2 & 0 & 0 & 5 & 1 & 1 & 16 & 17 & (145) \\
\hline Pakistan & 0 & 0 & 2 & 0 & 5 & 0 & 0 & 7 & 0 & 4 & 43 & 47 & (146) \\
\hline Palau & 0 & 1 & 0 & 0 & 0 & 0 & 0 & 1 & 0 & 2 & 1 & 3 & (147) \\
\hline Panama & 0 & 0 & 1 & 0 & 10 & 0 & 0 & 11 & 0 & 0 & 111 & 111 & (148) \\
\hline P.N.G. (7) & 1 & 0 & 13 & 0 & 12 & 0 & 1 & 27 & 10 & 34 & 57 & 91 & $(149)$ \\
\hline Paraguay & 0 & 0 & 1 & 0 & 4 & 0 & 0 & 5 & 0 & 0 & 49 & 49 & (150) \\
\hline Peru & 0 & 1 & 14 & 0 & 21 & 0 & 1 & 37 & 5 & 0 & 152 & 152 & (151) \\
\hline Philippines & 0 & 0 & 1 & 0 & 13 & 0 & 3 & 17 & 9 & 24 & 46 & 70 & (152) \\
\hline Poland & 0 & 0 & 5 & 0 & 3 & 0 & 0 & 8 & 0 & 0 & 23 & 23 & (153) \\
\hline Portugal & 0 & 0 & 8 & 0 & 5 & 0 & 0 & 13 & 1 & 0 & 24 & 24 & (154) \\
\hline Puerto Rico & 0 & 0 & 1 & 0 & 3 & 1 & 0 & 5 & 1 & 0 & 13 & 13 & (155) \\
\hline Qatar & 0 & 0 & 0 & 0 & 0 & 0 & 0 & 0 & 0 & 0 & 2 & 2 & (156) \\
\hline Réunion & 1 & 0 & 1 & 0 & 0 & 0 & 0 & 2 & 0 & 2 & 3 & 5 & (157) \\
\hline Romania & 0 & 0 & 7 & 0 & 6 & 0 & 0 & 13 & 0 & 0 & 26 & 26 & (158) \\
\hline Russia & 0 & 1 & 8 & 0 & 7 & 0 & 1 & 17 & 1 & 0 & 41 & 41 & (159) \\
\hline Rwanda & 0 & 0 & 1 & 0 & 3 & 0 & 0 & 4 & 0 & 8 & 33 & 41 & $(160)$ \\
\hline St. Kitts \& Nevis & 0 & 0 & 0 & 0 & 1 & 0 & 0 & 1 & 0 & 0 & 4 & 4 & $(161)$ \\
\hline St. Lucia & 0 & 0 & 0 & 0 & 3 & 0 & 0 & 3 & 0 & 0 & 8 & 8 & $(162)$ \\
\hline St. Vincent & 0 & 0 & 0 & 0 & 2 & 0 & 0 & 2 & 0 & 0 & 12 & 12 & $(163)$ \\
\hline Samoa & 0 & 1 & 0 & 0 & 0 & 0 & 1 & 2 & 0 & 2 & 2 & 4 & $(164)$ \\
\hline San Marino & 0 & 0 & 1 & 0 & 2 & 0 & 0 & 3 & 0 & 0 & 6 & 6 & $(165)$ \\
\hline São Tomé and Príncipe & 0 & 0 & 1 & 0 & 1 & 0 & 0 & 2 & 1 & 3 & 6 & 9 & $(166)$ \\
\hline Saudi Arabia & 0 & 0 & 4 & 0 & 4 & 0 & 0 & 8 & 0 & 2 & 21 & 23 & $(167)$ \\
\hline Senegal & 0 & 0 & 2 & 0 & 5 & 0 & 1 & 8 & 0 & 5 & 40 & 45 & $(168)$ \\
\hline Seychelles & 1 & 0 & 2 & 0 & 0 & 0 & 0 & 3 & 2 & 1 & 3 & 4 & (169) \\
\hline Sierra Leone & 0 & 0 & 0 & 0 & 9 & 0 & 1 & 10 & 0 & 10 & 46 & 56 & (170) \\
\hline Singapore & 0 & 0 & 1 & 0 & 0 & 0 & 1 & 2 & 1 & 5 & 4 & 9 & (171) \\
\hline Slovakia & 0 & 0 & 6 & 0 & 5 & 0 & 0 & 11 & 0 & 0 & 24 & 24 & (172) \\
\hline Slovenia & 0 & 0 & 7 & 0 & 5 & 0 & 0 & 12 & 0 & 0 & 27 & 27 & (173) \\
\hline Solomon Is. & 0 & 0 & 3 & 0 & 4 & 0 & 0 & 7 & 3 & 20 & 13 & 33 & $(174)$ \\
\hline Somalia & 0 & 0 & 1 & 0 & 6 & 0 & 0 & 7 & 0 & 2 & 35 & 37 & (175) \\
\hline South Africa & 0 & 0 & 5 & 0 & 10 & 0 & 2 & 17 & 3 & 4 & 52 & 56 & $(176)$ \\
\hline South Korea & 0 & 1 & 0 & 0 & 4 & 0 & 1 & 6 & 0 & 0 & 16 & 16 & (177) \\
\hline Spain & 0 & 0 & 9 & 1 & 4 & 0 & 0 & 14 & 1 & 0 & 27 & 27 & (178) \\
\hline Sri Lanka & 0 & 0 & 0 & 0 & 2 & 0 & 0 & 2 & 0 & 4 & 28 & 32 & (179) \\
\hline Sudan & 0 & 0 & 3 & 0 & 10 & 0 & 0 & 13 & 0 & 9 & 58 & 67 & $(180)$ \\
\hline Suriname & 0 & 0 & 3 & 0 & 9 & 0 & 2 & 14 & 0 & 0 & 62 & 62 & (181) \\
\hline Swaziland & 0 & 0 & 0 & 0 & 1 & 0 & 0 & 1 & 0 & 3 & 17 & 20 & (182) \\
\hline Sweden & 0 & 0 & 3 & 0 & 0 & 0 & 0 & 3 & 0 & 0 & 16 & 16 & (183) \\
\hline Switzerland & 0 & 0 & 4 & 0 & 5 & 0 & 0 & 9 & 0 & 0 & 26 & 26 & $(184)$ \\
\hline Syria & 0 & 0 & 1 & 0 & 4 & 0 & 0 & 5 & 0 & 1 & 10 & 11 & $(185)$ \\
\hline Taiwan & 0 & 0 & 2 & 0 & 2 & 0 & 1 & 5 & 4 & 0 & 20 & 20 & $(186)$ \\
\hline Tajikistan & 0 & 0 & 2 & 0 & 3 & 0 & 0 & 5 & 0 & 0 & 19 & 19 & $(187)$ \\
\hline Tanzania & 0 & 0 & 2 & 0 & 13 & 0 & 3 & 18 & 2 & 13 & 66 & 79 & $(188)$ \\
\hline Thailand & 0 & 2 & 2 & 0 & 21 & 0 & 3 & 28 & 4 & 17 & 91 & 108 & $(189)$ \\
\hline Togo & 0 & 0 & 0 & 0 & 3 & 0 & 0 & 3 & 0 & 9 & 31 & 40 & (190) \\
\hline Tonga & 0 & 1 & 0 & 0 & 0 & 0 & 0 & 1 & 0 & 1 & 1 & 2 & $(191)$ \\
\hline Trinidad and Tobago & 0 & 0 & 0 & 0 & 5 & 0 & 0 & 5 & 0 & 0 & 63 & 63 & (192) \\
\hline Tunisia & 0 & 0 & 4 & 0 & 3 & 0 & 0 & 7 & 0 & 0 & 12 & 12 & (193) \\
\hline Turkey & 0 & 0 & 7 & 0 & 6 & 0 & 0 & 13 & 0 & 1 & 30 & 31 & (194) \\
\hline Turkmenistan & 0 & 0 & 3 & 0 & 3 & 0 & 0 & 6 & 0 & 0 & 21 & 21 & (195) \\
\hline Turks and Caicos Islands & 0 & 0 & 0 & 0 & 2 & 0 & 0 & 2 & 0 & 0 & 7 & 7 & (196) \\
\hline Uganda & 0 & 0 & 1 & 0 & 13 & 0 & 0 & 14 & 0 & 11 & 51 & 62 & (197) \\
\hline Ukraine & 0 & 0 & 5 & 0 & 4 & 0 & 0 & 9 & 0 & 0 & 27 & 27 & $(198)$ \\
\hline U. A. E. (8) & 0 & 0 & 0 & 0 & 0 & 0 & 0 & 0 & 0 & 0 & 6 & 6 & (199) \\
\hline United Kingdom & 0 & 0 & 3 & 0 & 3 & 0 & 0 & 6 & 0 & 0 & 16 & 16 & $(200)$ \\
\hline United States & 0 & 3 & 4 & 0 & 4 & 0 & 0 & 11 & 3 & 0 & 45 & 45 & $(201)$ \\
\hline Uruguay & 0 & 0 & 1 & 0 & 1 & 0 & 0 & 2 & 0 & 0 & 15 & 15 & (202) \\
\hline
\end{tabular}




\begin{tabular}{|c|c|c|c|c|c|c|c|c|c|c|c|c|c|}
\hline \multirow[b]{2}{*}{ Country } & \multicolumn{8}{|c|}{ IUCN Red List species } & \multirow{2}{*}{$\begin{array}{l}\text { Total } \\
\text { endemics }\end{array}$} & \multicolumn{4}{|c|}{ Total species } \\
\hline & CR & EN & $\mathrm{VU}$ & LRcd & LRnt & EX & DD & Total & & Mega & Micro & Total & Source \\
\hline Uzbekistan & 0 & 0 & 3 & 0 & 4 & 0 & 0 & 7 & 0 & 0 & 21 & 21 & (203) \\
\hline Vanuatu & 0 & 0 & 0 & 0 & 1 & 0 & 0 & 1 & 0 & 4 & 7 & 11 & (204) \\
\hline Vatican City (9) & - & - & - & - & - & - & - & - & - & - & - & - & \\
\hline Venezuela & 0 & 0 & 6 & 0 & 23 & 0 & 3 & 32 & 3 & 0 & 154 & 154 & $(205)$ \\
\hline Viet Nam & 1 & 1 & 2 & 0 & 10 & 0 & 1 & 15 & 1 & 11 & 53 & 64 & (206) \\
\hline Wallis \& Futuna Islands & 0 & 0 & 0 & 0 & 0 & 0 & 0 & 0 & 0 & 1 & 0 & 1 & $(207)$ \\
\hline Yemen & 0 & 0 & 2 & 0 & 3 & 0 & 0 & 5 & 0 & 2 & 22 & 24 & $(208)$ \\
\hline Yugoslavia & 0 & 0 & 8 & 0 & 5 & 0 & 0 & 13 & 0 & 0 & 26 & 26 & (209) \\
\hline Zambia & 0 & 0 & 2 & 0 & 8 & 0 & 0 & 10 & 0 & 11 & 54 & 65 & $(210)$ \\
\hline Zimbabwe & 0 & 0 & 2 & 0 & 8 & 0 & 1 & 11 & 0 & 6 & 55 & 61 & (211) \\
\hline
\end{tabular}

Notes:

(1) - Central African Republic

(2) - Commonwealth of the Northern Mariana Islands

(3) - Democratic Republic of Congo (formerly Zaire)

(4) - Only two bats have been recorded from the Falkland Islands, both probable imports.

(5) - Federated States of Micronesia

(6) - The only bats recorded from Iceland are vagrants.

(7) - Papua New Guinea

(8) - United Arab Emirates

(9) - As far as the authors are aware, there is no information on bats in the Vatican City.

SOURCES: (1) - Corbet, 1978, (2) - Mitchell-Jones et al., 1999, (3) - Gaisler, 1983-84; Kowalski \& Rzebik-Kowalska, 1991, (4) - Mickleburgh et al., 1992; Koopman, 1993; Flannery, 1995b, (5) - McFarlane, 1991, (6) - S.S. Guitart, pers. comm., (7) - Bergmans, 1988, 1989, 1990, 1994, 1997; Skinner \& Smithers, 1990, (8) - Breuil \& Masson, 1991; McFarlane, 1991, (9) - Breuil \& Masson, 1991; McFarlane, 1991, (10) - Barquez et al., 1999, (11) - E.G. Yavrovyan, pers. comm, (12) - Husson, 1960, (13) - Churchill, 1998, (14) - F. Spitzenberger, pers. comm., (15) - Rakhmatulina, 1989, 1996a,b, (16) - Koopman et al., 1957; Hill, 1985, (17) - Harrison \& Bates, 1991, (18) - Bates \& Harrison, 1997, (19) - McFarlane, 1991, (20) - A. Borissenko, pers. comm., (21) - J. Fairon, pers. comm., (22) - McCarthy et al., 1993, (23) - Robbins, 1980, (24) - Koopman, 1993, (25) - Bates \& Harrison, 1997, (26) - L.F. Aguirre, pers. comm., (27) - Mitchell-Jones et al., 1999, (28) - Taylor, 2000, (29) - da Fonseca et al., 1996; Marinho-Filho \& Sazima, 1998, (30) - McFarlane, 1991, (31) - Payne et al. 1985, (32) - V. Beshkov \& R. Pandurska, pers comm., (33) - Koch-Weser, 1984, (34) - Bergmans, 1988, 1989, 1990, 1994, 1997; Kock, 1981, (35) - Corbet \& Hill, 1992, (36) - Mickleburgh et al., 1992; Hayman \& Hill, 1971, (37) - van Zyll de Jong, 1985, (38) - Koopman, 1993, (39) - McFarlane, 1991, (40) - Mickleburgh et al., 1992; Schlitter et al., 1983, (41) - Vielliard, 1974, (42) - Redford \& Eisenberg, 1992, (43) - Zhang Yongzu, 1997, (44) - Rodriguez-Mahecha et al., 1995, (45) - Mickleburgh et al., 1992; Flannery, 1995b, (46) - Cheke \& Dahl, 1981; Mickleburgh et al., 1992, (47) - Bergmans, 1988, 1989, 1990, 1994, 1997; Hayman \& Hill, 1971, (48) - Mickleburgh et al., 1992, (49) - Rodriguez \& Wilson, 1999, (50) - Koopman et al., 1995, (51) - MitchellJones et al., 1999, (52) - Silva-Taboada, 1978, (53) - Mickleburgh et al., 1992; Boye et al., 1990, (54) - Hanak et al., 1995, (55) - Bergmans, 1988,1989, 1990, 1994, 1997; Hayman \& Hill, 1971, (56) - Baagøe, 2001, (57) - Pearch et al., in press, (58) - McFarlane, 1991, (59) - McFarlane, 1991, (60) - Albuja Viteri, 1999, (61) - Qumsiyeh, 1985, (62) - McCarthy et al., 1993, (63) - Bergmans, 1988, 1989, 1990, 1994, 1997; J. Juste, pers. comm., (64) - Hayman \& Hill, 1971, (65) - M. Masing, pers. comm., (66) - Bergmans, 1988, 1989, 1990, 1994, 1997; D. Yalden, pers. comm., (67) - Hill, 1988; A.M. Hutson, pers. comm., (68) - Mickleburgh et al., 1992; Flannery, 1995b, (69) - Mickleburgh et al., 1992; Flannery, 1995b, (70) - T. Stjernberg, pers. comm., (71) - Mitchell-Jones et al., 1999, (72) - Simmons et al., 2000, (73) - Bergmans, 1988, 1989, 1990, 1994, 1997; Hayman \& Hill, 1971, (74) - Grubb et al., 1998, (75) - I. Rakhmatulina, pers. comm., (76) - Mitchell-Jones et al., 1999, (77) - Grubb et al., 1998, (78) - Stebbings, 1988, (79) - Karandinos \& Paraschi, 1992, (80) - Breuil \& Masson, 1991, (81) - Breuil \& Masson, 1991, (82) - Mickleburgh et al., 1992; Flannery, 1995a, (83) - McCarthy et al., 1993, (84) - Koopman et al., 1995, (85) - A. Rainho, pers. comm., (86) - Smith \& Kerry, 1996; Lim et al., 1999, (87) - Klingener et al., 1978; Mcfarlane, 1991, (88) - McCarthy et al., 1993, (89) - Dobrosi, 1995, (90) - Petersen, 1994, (91) - Bates \& Harrison, 1997, (92) - Mickleburgh et al., 1992, Corbet \& Hill, 1992; Koopman, 1993, (93) - DeBlase, 1980, (94) - Harrison \& Bates, 1991, (95) - O'Sullivan, 1994, (96) - Mendelssohn \& Yom-Tov, 1999, (97) - Vernier, 1997, (98) - McFarlane, 1991, (99) - Yoshiyuki, 1989, (100) - Harrison \& Bates, 1991, (101) - A.V. Polkanov, pers. comm., (102) - Mickleburgh et al., 1992; Aggundey \& Schlitter, 1985, (103) - Harrison \& Bates, 1991, (104) - Rybin et al., 1989, (105) - Francis et al., 1999, (106) - G. Petersons, pers. comm., (107) - Harrison \& Bates, 1991, (108) - Taylor, 2000, (109) - Koopman et al., 1995, (110) - Hayman \& Hill, 1971; Qumsiyeh \& Schlitter, 1982, (111) - S. Hoch, pers. comm., (112) - Pauza \& Panziene, 1998, (113) - J. Pir, pers. comm., (114) - Krystufek et al., 1992, (115) - Mickleburgh et al., 1992; Peterson et al., 1995; Garbutt, 1999, (116) - Happold et al., 1987; D.C.D. \& M. Happold, pers. comm., (117) - Corbet \& Hill, 1992, (118) - Mickleburgh et al., 1992, (119) - Mickleburgh et al., 1992; Hayman \& Hill, 1971, (120) - Borg et al., 1997, (121) - Breuil \& Masson, 1991; McFarlane, 1991, (122) - Hayman \& Hill, 1971, (123) - Mickleburgh et al., 1992; Cheke \& Dahl, 1981, (124) - Mickleburgh et al., 1992; Cheke \& Dahl, 1981, (125) - Medellin et al., 1997, (126) - S. Andreev, pers. comm., (127) - C. Joulot, pers. comm., (128) - Mallon, 1985, (129) - Breuil \& Masson, 1991; McFarlane, 1991, (130) - Aulagnier \& Thevenot, 1986, (131) - Taylor, 2000, (132) - Bates et al., 2000, (133) - Taylor, 2000, (134) - Bates \& Harrison, 1997; Csorba et al., 1999, (135) - Limpens et al., 1997, (136) - Husson, 1960, (137) - Mickleburgh et al., 1992; Flannery, 1995b, (138) - King, 1995, (139) - McCarthy et al., 1993, (140) - Mickleburgh et al., 1992; Hayman \& Hill, 1971, (141) - Happold, 1987, (142) - Mickleburgh et al., 1992, (143) - G. Csorba, pers. comm., (144) - Isaksen et al., 1998, (145) - Harrison \& Bates, 1991, (146) - Bates \& Harrison, 1997, (147) - Mickleburgh et al., 1992; Flannery, 1995a, (148) - Eisenberg, 1989; Reid, 1997, (149) - Bonaccorso, 1998, (150) - Redford \& Eisenberg, 1992, (151) - Pacheco et al., 1995, (152) - Heaney et al., 1987; Ingle \& Heaney, 1992, (153) - Mitchell-Jones et al., 1999, (154) - Palmeirim, 1989, (155) - McFarlane, 1991; 
Rodriguez-Duran \& Kunz, 2001, (156) - Harrison \& Bates, 1991, (157) - Cheke \& Dahl, 1981, (158) - Mitchell-Jones et al., 1999, (159) - A. Borissenko \& S.V. Kruskop, pers. comm., (160) - Mickleburgh et al., 1992; Baeten et al., 1984, (161) - McFarlane, 1991, (162) - Breuil \& Masson, 1991; McFarlane, 1991, (163) - Vaughan \& Hill, 1996, (164) - Mickleburgh et al., 1992; Flannery, 1995b, (165) - D. Scaravelli, pers. comm., (166) - Juste \& Ibanez, 1993, (167) - Harrison \& Bates, 1991, (168) - Mickleburgh et al., 1992; Hayman \& Hill, 1971; Koopman, 1993, (169) - Hill, 1971, Mickleburgh et al., 1992; Gerlach, 1997, (170) - Grubb et al., 1998, (171) - Mickleburgh et al., 1992; Corbet \& Hill, 1992, (172) - M. Uhrin, pers. comm., (173) - Krystufek, 1991; Krystufek \& Cerveny, 1997, (174) - Mickleburgh et al., 1992; Flannery, 1995b, (175) - Bergmans, 1988, 1989, 1990, 1994, 1997; Hayman \& Hill, 1971, (176) - Taylor, 2000, (177) - G. Csorba, pers. comm., (178) - Benzal \& de Paz, 1991, (179) - Bates \& Harrison, 1997, (180) - Bergmans, 1988, 1989, 1990, 1994, 1997; Kock, 1969; Koopman, 1975, (181) - Husson, 1962, (182) - Taylor, 2000, (183) - Mitchell-Jones et al., 1999, (184) - Moeschler, 1991, (185) - Harrison \& Bates, 1991, (186) - Hsu, 1997, (187) - Khabilov, 1989, (188) - Mickleburgh et al., 1992; Bauer, 1992, (189) - Lekagul \& McNeely, 1977; B. Stewart-Cox, pers. comm., (190) - Bergmans, 1988, 1989, 1990, 1994, 1997; Grubb et al., 1998, (191) - Mickleburgh et al., 1992; Flannery, 1995b, (192) - Breuil \& Masson, 1991, (193) - Hayman \& Hill, 1971; Koopman, 1993, (194) - Benda \& Horacek, 1998, (195) - T. Khabilov \& A. Borissenko, pers. comm., (196) - A.M. Hutson, pers. comm., (197) - Bergmans, 1988, 1989, 1990, 1994, 1997; Kingdon, 1974, (198) - A-T. Bashta, pers. comm., (199) - Harrison \& Bates, 1991, (200) - Harris et al., 1995, (201) - Barbour \& Davis, 1969; Pierson, 1998, (202) - Redford \& Eisenberg, 1992, (203) - T. Khabilov, pers. comm., (204) - Mickleburgh et al., 1992; Flannery, 1995a, (205) - Linares, 1998, (206) - Corbet \& Hill, 1992; Bates et al., 1997, (207) - Mickleburgh et al., 1992, (208) - Harrison \& Bates, 1991, (209) - Savic et al., 1995; Paunovic et al., 1998, (210) - Mickleburgh et al., 1992; Ansell, 1978, (211) - Taylor, 2000. 